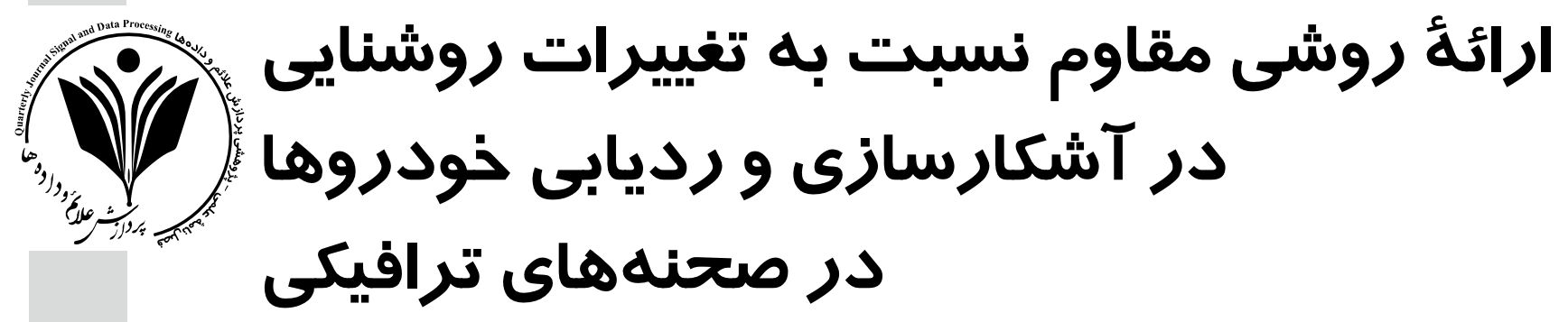

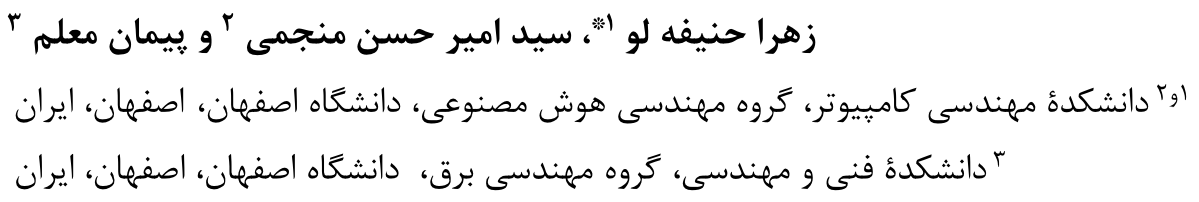

جكبده

در اين مقاله روشسى ســريع مبتنى بر يردازشهاى هوشـمند تصوير، جهت آشكارسازى و رديابى خودروهاى متحرك در تقاطعها ارائه شده

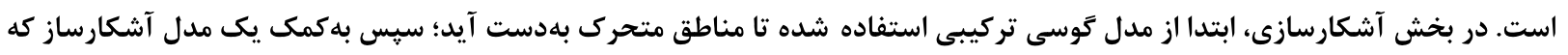

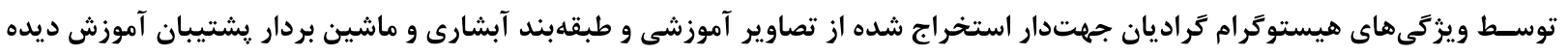

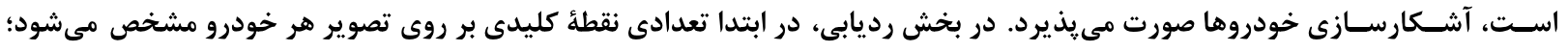

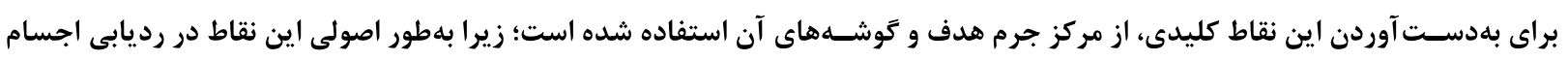

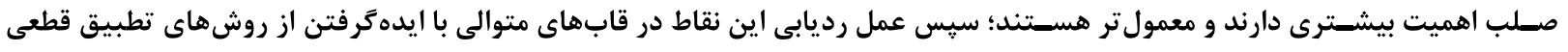

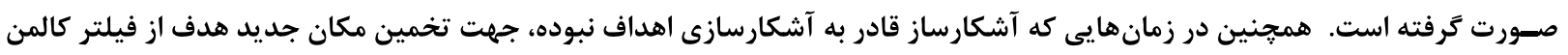

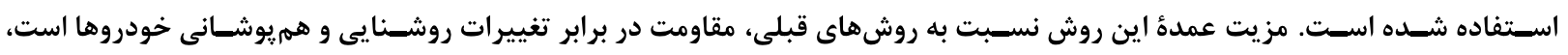

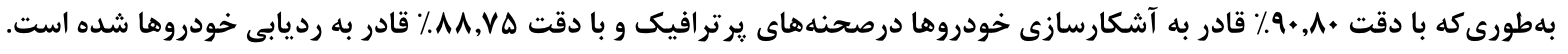
وازَان كليدى: آشكارسازى، رديابى بصرى، Ada-boost HOG، فيلتر كالمن، رديابى خودرو، روشهاى تطبيق قطعى نقاط، تابع هزينه

\title{
Robust method of changes of light to detect and track vehicles in traffic scenes
}

\author{
Zahra Hanifelou ${ }^{*}$, Seyed Amir Hassan Monadjemi² \& Payman Moallem ${ }^{3}$ \\ Faculty of computer engineering, University of Isfahan, Isfahan, Iran lir \\ ,Faculty of Engineering, Department of Electrical Engineering, University of Isfahan ${ }^{r}$ \\ Isfahan, Iran
}

\begin{abstract}
In this paper, according to the detection and tracking of the moving vehicles at junctions, a rapid method is proposed which is based on intelligent image processing. In the detection part, the Gaussian mixture model has been used to obtain the moving parts. Then, the targets have been detected using HOG features extracted from training images, Ada-boost Cascade Classifier and the trained SVM. At the tracking part, a number of key points on the image of the vehicle were identified at first. The center of mass of the object and the edges were used to obtain these key points because these points are primarily important and more common in tracking rigid bodies. Then, these points were tracked in consecutive frames using definitive adaptive
\end{abstract}


procedures. Also, the Kalman filter has been used to estimate new locations when the detector is not able to detect the targets. The major advantage of this method in comparison with the previous methods is its resistance against vehicle's overlapping and changes in Illuminations, so that the detection accuracy is $90.80 \%$ on overloaded traffic scenes and $88.75 \%$ on the tracking vehicles.

Keywords: Detection, Tracking, Ada-boost, Kalman Filter, Vehicle tracking, Deterministic Methods Corresponding, Cost Function

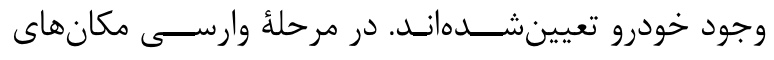

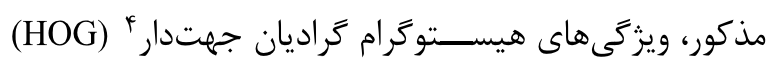
اسـتخراج و از دسـتهبند SVM استفاده شده و نتايج مطلوبى هرئ حاصل شده است.

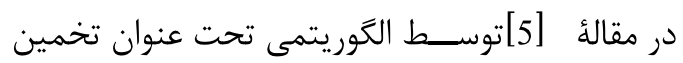
وفقى يسزمينه (ABE)، با تنظيم وفقى نرخ بههنكامســازى يسزمينه، در نواحى مختلف تصـوير، اثر هالهاى حذف شـده

در مقالهٔ [6] از مدل افاين "براى طبقهبندى بردارهاى حركت تصـوير بممنظور آشـكارسـازى ناحئ خودرو اسـتفاده شده است. در اين روش، شرط آشكارسازى خودرو در صحنه SVehicle اســت كـه در آن SVehicle>0.5SBackgrou SBackground, بـهترتيـب مســاحـتهاى وســيلة نقليه و يسزمينه هستند.

در بخش رديابى خودروها از ديدكاههاى معمول جهت

رديابى خودروها به اسـتفاده از ميدانهاى تصـادفى مكانى و و ردابـ

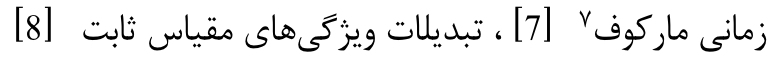

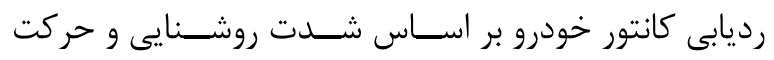

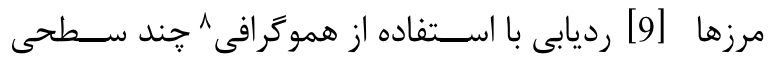

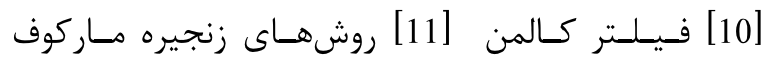

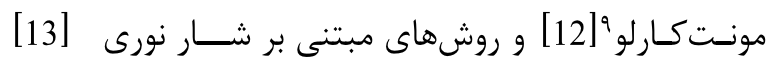

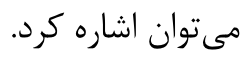

در مقـالـأ [14]يـك الكوريتهم توسـعلهيافته، به نام

ميـدانهـاى تصــادفى مكسانى_زمانى ماركوف، براى تحليل تصــاوير ترافيكى در تقاطعها يِيشــهاد شـده اسـت. در اين روش، رديـابى با تعيين موقعيت هر بِيكســل در تصــوير و

\footnotetext{
${ }^{4}$ Histogram of Oriented Gradients

${ }^{5}$ Adaptive Background Estimation

${ }^{6}$ Affine

${ }^{7}$ Markov

${ }^{8}$ Homography

${ }^{9}$ Monte Carlo
}

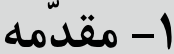

رديابى اشسيا' درواقع تعيين مسـير حركت يك شىء در طول

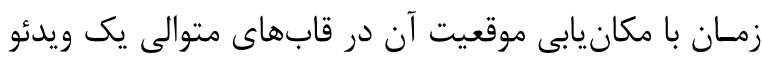
اسـت و يكى از مههترين زمينههاى كارى در ماشـين بينايى

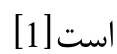
در ســــالهـاى اخـير روشهـاى مختلفى جهـت آشـكارسـازى و رديابى خودروها معرفىشـده اسـت؛ ازجمله

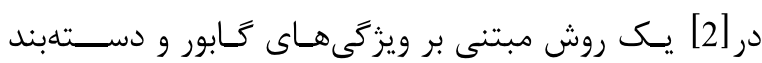

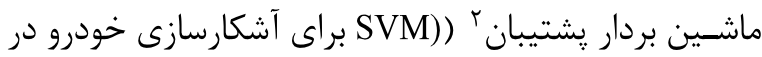
سطح جاده و خيابان ارائه شد. در اين مقاله جهت مقايسه از ويزگكىهاى مبتنى بر تحليل اجزاى اصـلى و دسـتلابند شبكأ عصـبى نيز اسـتفاده شد. مقايسهاى انجامشده نشان داد كه ويزگى هاى كابور و دســتهبند SVM عملكرد بهترى از خود نشان مى دهند.

در [3]يك روش جديد براى آشـكارسـازى خودرو از زاويه ديد عقب در ســطح جاده و خيابان ارائه شــد. در اين روش براى ساخت فرضيه از تركيب روشهاى سايه و قرينكى اسـتفاده شـده اسـت و نيازى به آشكارسازى باندهاى خيابان نيسـ؛ به اين صـورت كه ابتدا سائُ زير خودرو آشكارسازى

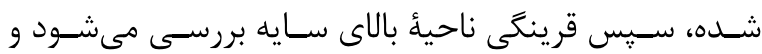

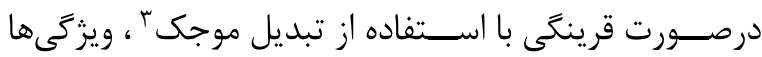
استخراج مىشوند. در اين يزوهش از دستهبند SVM با كرنل كوسى استفاده شده است.

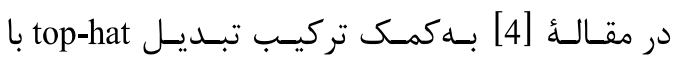
خصـوصيت قرينگى لبهها و شدت تصوير، مكانهاى احتمالى

${ }^{1}$ Object Tracking

${ }^{2}$ support vector machine

${ }^{3}$ Wavelet Transform 
خودروها يا كل آنها باهم، شـكل ( ا ج) و همجنين تغييرات

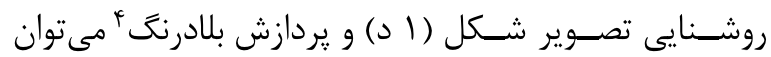

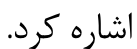

در اين مقاله روشـى سـريع و مقاوم در برابر تغييرات شـرايط نورى و هم:يوشـانى خودروها، جهت رديابى خودروها در تقاطعها و صحنههاى برترافيك ارائه شده است. نوآورى اين مقاله درواقع شـامل دو بخش است: بخش نخســت اســـفــاده از تركيب ويزگگى هاى مختلف در مرحلة

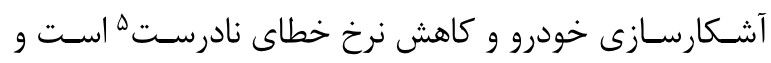
همجنين در بخش رديابى خودرو، استفاده از الكوريتم رديابى كالمن اسـت. بهطورى كه در شرايطى كه خودروها هميوشانى دارند يا از صـــنه خارجشــدهاند هم الكوريتم قادر به رديابى خودروها باشد. در ادامه و در بخش r دادههاى مورد اســتفاده معرفى و در بخش r روش ارائهشـده جهت آشـكارسـازى خودروها معرفى مىشـود؛ سـيس در بخش f دو روش رديابى نقطهاى معرفى خواهد شـد و در بخش ه به معرفى روش ييشـنهادى رديابى يرداخته خواهد شد، در بخش 9 هم نتايج الكوريتم بر روى تصاوير واقعى بيان شده است.

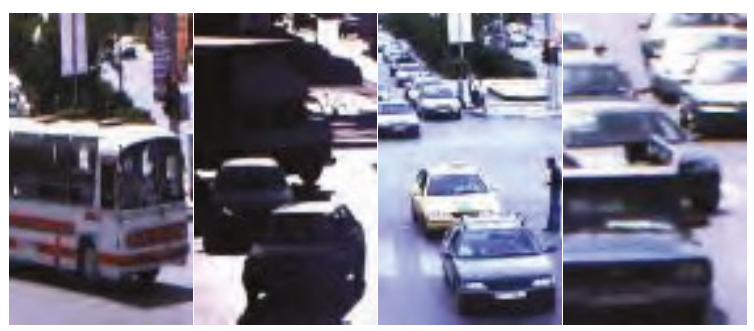

$\checkmark$

ج

$\varphi$ الف - - -

(شكل - (): يِيجيدكىهاى موجود در تشخيص خودرو در صحنه هاى ترافيكى

(Figure-1): vehicles detection complexities in traffic scenes

\section{r- دادههاى مورد استفاده}

دادههـاى موردنيـاز براى الكوريتم زيشــــهــادى بهصــورت

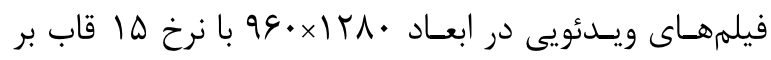
ثانيه و با فرمت MPEG4 اسـت كه توســط دوربينى كه در

${ }^{3}$ Occlusion

${ }^{4}$ Real Time

${ }^{5}$ False Alarm
جابهجايى آن، و خكَونكى جابهجايى موقعيت هر ريكسـل در امتداد هر دو محور X و Y تصوير نسبت به محور زمان انجام مىشــود. اين الكوريتم براى بخشبندى و رديابى وســايل نقليهاى كه دجار هميوشـــانى مى شـــــنه، عملكرد تاحدودى مناسـب دارد. عملكرد مطلوب اين سـامانه، منجر به توسـعـ يك سـامانهٔ تشخيص ڤايدار و قابل گسترش رويداد، مبتنى بر مدل مخفى ماركوف ' (HMM) شــده اســـت. اين ســامانه الكوهـاى رفتارى رويدادهاى مختلف هر وســـيله نقليه را در زنجيره HMM آموزش مىبيند و يس از آن، با اســتفاده از خروجى سـامانهُ رديابى، زنجيره رويدادهاى فعلى را شناسايى مى كند. اين ســامانه مى تواند ضـــربات ناگمانى حاصــل از انـدازهاى مســـير حركـ، عبور و مرور خودروهـا، و تراكم و فشــردكى خودروها (ترافيك) را تشــخيص دهد. بهعلاوه، با

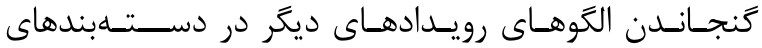
آموزشـى '، سامانه را براى آشكارسازى رويدادهايى مانند دور

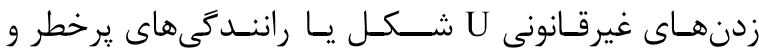
زيخزاكى، مىتوان توسعه داد.

همرجنين در مقـالـهُ [15] بـا توجــه به تجزيهوتحليل جنــدمقيـاســى تبديل كانتورلت، الخوريتم رديابى ويدئويى خودرو مبتنى بر تبديل كانتورلت مطرح شـده است. در ابتدا، بر اسـاس ويزگگ هاى ثابت از روى تصساوير دوربين نظارت بر

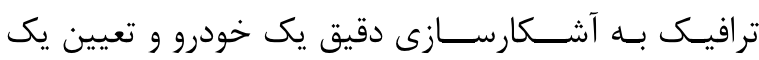
مســـطيل اطراف آن با اســـفاده از روش كاهش گِيسزمينه رسـيدهاند. يس از آن، با استفاده از تبديل كانتورلت براى اين منطقه از خودرو، طيف اطلاعات خودروها را دريافت مى كنند. اين الكوريتم توانسايى رديابى خودروها را بهصـورت بلادرنگ دارد

اما رديابى تصــويرى خودروها يِيجيدگى هاى زيادى دارد؛ ازجمله اين ييجيدگى ها به از دســت دادن اطلاعات در تصوير كردن دنياى سهبعدى به تصاوير دوبعدى، نوفه تصاوير، حركات ييجيده خودروها تنوع زياد خودروها در شكل، اندازه و رنگً، تغيير ظاهر خودرو توجه به زاوئٔ قرارگيرى آن خودرو در برابر دوربين شـكل (1 الف و ب) و هم:يوشانى ب قسمتى از

\footnotetext{
${ }^{1}$ Hidden Markov Model (HMM) ${ }^{2}$ Training Set
} 


\section{r- آشكارسازى خودروها}

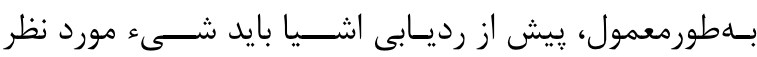
آشـكارسـازى شود. بهطور كلى روشهاى آشكارسازى خودرو لئر

شامل دو مرحله است: [17] - 17

در مرحلة نخسـت كه ساخت فرضيه بناميده مىشود،

محـلهـايى كه احتمال مى دهيم خودرو در آنها وجود دارد، مشخص شده و بلعنوان فرضيه در نظر كرفته مى شود؛ سيس

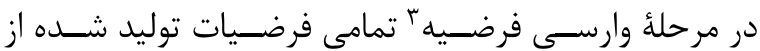
مرحلة قبل وارسسى شده تا وجود يا عدم وجود خودرو تعيين شـود. در شـكل ץ يك سـامانهُ آشكارسازى خودرو به تصوير كشـيده شـده اسـت. در شـكل ب(ب) مكانهايى كه احتمال وجود خودرو در آنها اسـت مشـخص شـده (مرحلة سـاخت فرضـيه) و در شـكل ؟ (ج) مكانهاى حاصـل از مرحلة قبل

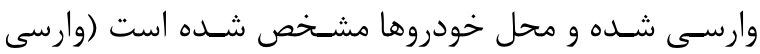$$
\text { فرضيه). }
$$

در اين مقاله جهت آشـارسازى خودروهاى متحرى،

سـه روش مختلف بررسـى شـده اسـت و درنهايت روشى كه

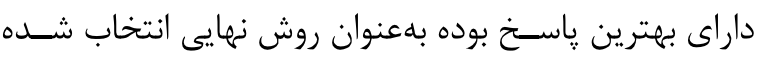
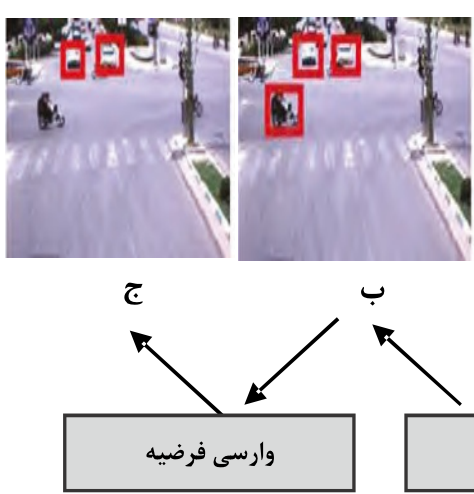

(شكل - "): دو مرحلةً اصلى سامانهُ آشكارسازى خودرو

(Figure- 3): The two-step Vehicle Detection Strategy

روش نخست: ابتدا براى ساخت فرضيه از مدل گوسى

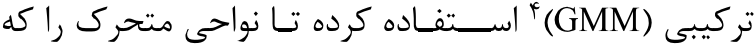
نامزد وجود خودرو و سـاير اشـيا متحرك مىباشند استخراج

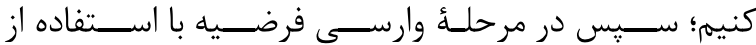
ويزگى هاى شبه- هار ه كه توسط الخوريتم AdaBoost آموزش

${ }^{4}$ Gaussian mixture models(GMM)

${ }^{5}$ Haar-Like Feature
فاصلهُ پانزده مترى از جهار راه و ارتفاع هفت مترى از آن قرار دارد، در ســـاعـات مختلف روز و شـــرايط مختلف نورى فيلمبردارى شــده اســ. همجنِين جهت مقايسـهـ الكوريته بيشــهادى، با سـاير يزوهشهاى انجامشده در اين زمينه، از تعدادى دادَان همكانى و استاندارد نيز استفاده شده است.

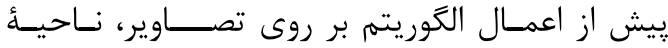

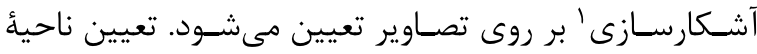
آشـكارسـازى يكى از مهمترين بخشهاى اين الكوريتم است كه باعث مىشـود بسيارى از نواحى متحرك در تقاطع شبيه

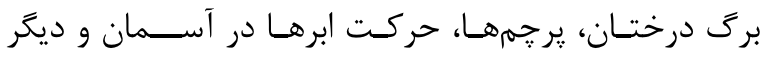
قسـمتهايى كه با توجه به تغييرات روشـنايى يا باد ممكن

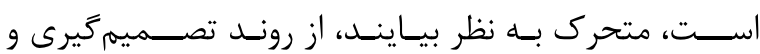

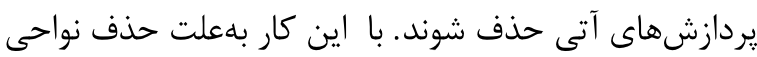

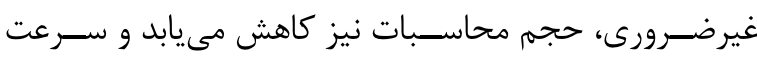
برنامه افزايش مىيابد. براى يافتن ناحية آشـكارسـازى، بايد خط توقف راكسه يك خط ســفيد افقى اسـت و در جهت مشـصـى در تقاطع فرض مىشود يا وجود دارد تعيين كرد؛ ســـ با تعيين لبههاى كنارى مســيرها و تعيين ناحيهاى

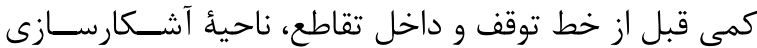

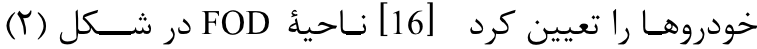
مشاهده مىشود. يس از تعيين ناحية FOD Fمل آشكارسازى خودروها

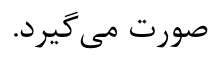

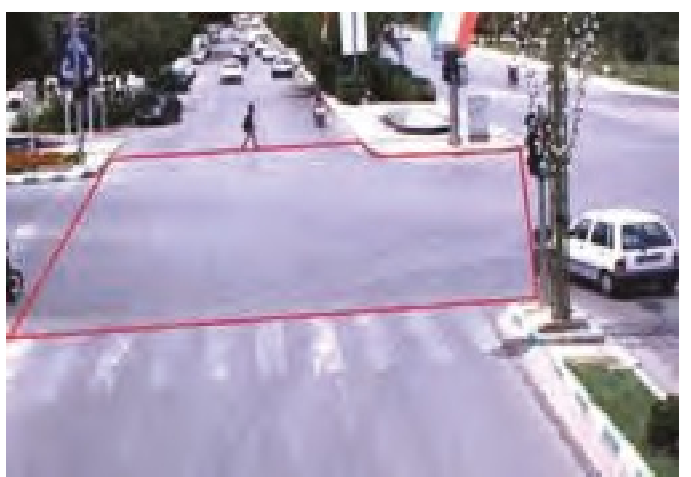

(شكل- Y): ناحيئ آشكارسازى FOD در تصوير اصلى (Figure- 2): Field of Detection in the original image

\footnotetext{
${ }^{1}$ Field of Detection

${ }^{2}$ Hypothesis Generation

${ }^{3}$ Hypothesis Verification
} 


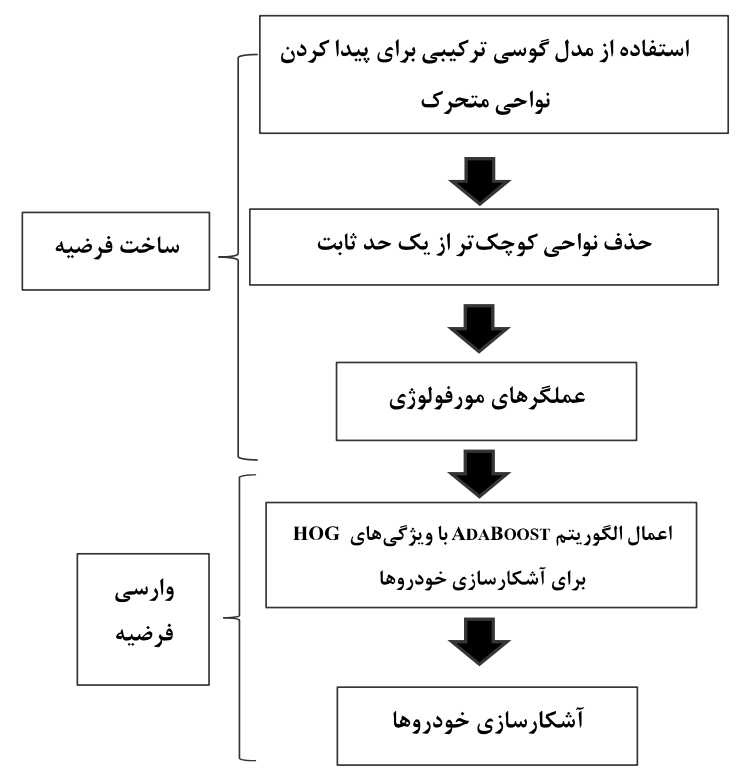

(شكل - F): روندنماى روش نخست آشكارسازى خودروها

(Figure- 4): The diagram of the vehicles detection.

در اين روش ابتدا همة توزيعها بر اســـاس

مىشـوند كه O و واريانس توزيع اسـت؛ ســـ هر پيكسـل جديد xt با توزيعها مقايسه مىشود، و نخستين توزيعى كه

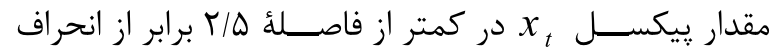

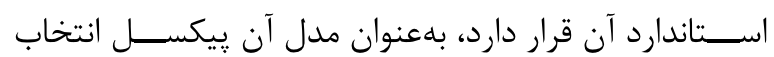
مىشــود. بعدازاين كه مدل קيكســل انتخاب شــد، ميانگين و

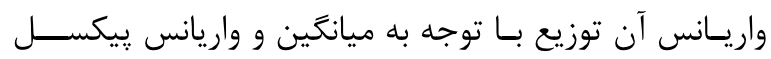

$$
\text { جديد بلهروزرسانى مىشود. }
$$

همجنين وزن هر توزيع در هر مرحلـه با توجه به نرخ

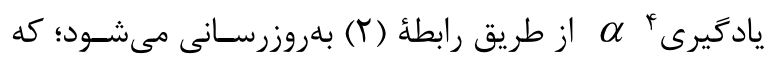
M M,t باقى مانده، صفر است.

$\omega_{k, t}=(1-\alpha) \omega_{k, t-1}+\alpha M_{k, t}$

در اين يزوهش مقدار نرخ يادگيرى ل م برابر ا •,. در نظر كرفته شده است.

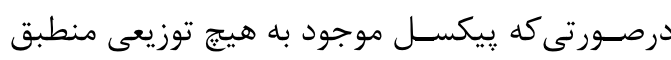

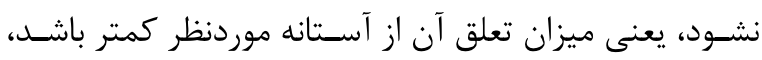

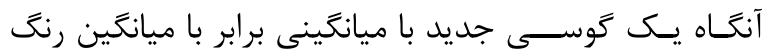
بيكسل جارى و يك واريانس اوليه ايجاد مىشود.
ديسدهاند، از بين نواحى نامزد، تصــاوير خودروها اســتخراج مى شود.

روش دوم: در اينجا هم ابتدا از مدل گوســى تركيبى براى سـاخت فرضـيه و درنتيجه اسـتخراج مناطق متحرى

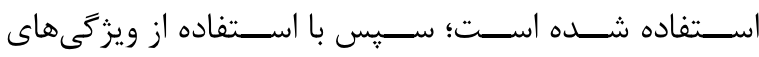
هـيســتـوخـرام گـراديــان جهـتدار (HOG)' و الخوريتم AdaBoost مىشود.

روش ســوم: در اين روش هم پس از تعيين نواحى متحرك، توسسط تركيب طبقهبند SVM و Ada-boost كه با ويزگى هاى HOG از تصساوير آموزشسى استخراجشده، آموزش ديده اسـت، نواحى متحرك به دو دستهٔ خودرو و غير خودرو تقسـيممبندى مى شـوند و بدين ترتيب آشـكارسازى خودروها صورت مى خيرد.

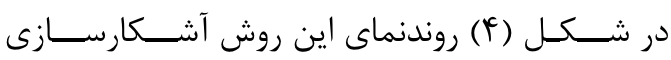
خودروها نشان داده شده است.

\section{ب-1- مدل تَوسى تركيبى}

در مدل گوسـى تركيبى، از تركيب جند توزيع گوسـى براى

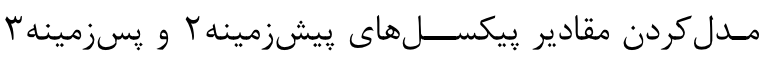

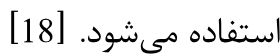

$p_{\left(x_{t}\right)}=\sum_{i=1}^{k} \omega_{i, t} \times \eta\left(x_{t}, \mu_{i, t}, \Sigma_{i, t}\right)$

در اين رابطه k تعداد توابع گَوسـىى، كوســى در زمـان كوواريانس i-امين گوسى در تركيب گوسىها در زمان t و يك جگًالى توزيع احتمال گوسـى اسـت. همهٔ وزنها در فريم جديد بهروزرسانى مىشوند. همجنين تعداد توابع كوسـى ميانخين و كوواريانس اولية آنها در ابتدا تعيين مىشود، در اين سامانه تعداد جهار تابع گوسى با واريانس اوليه بيست در نظر گرفتهايم.

\footnotetext{
${ }^{1}$ Histogram of Oriented Gradients (HOG)

${ }^{2}$ foreground

${ }^{3}$ background
} 
$\mathrm{ii}(x, y)=\sum_{x^{\prime} \leq x, y^{\prime} \leq y} \mathrm{i}\left(x^{\prime}, y^{\prime}\right)$

كه در آن

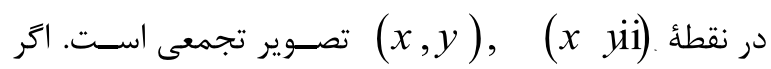
s(x,y)

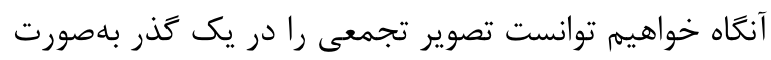

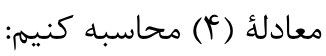

$s(x, y)=s(x, y-1)+\mathrm{i}(x, y)$,

$s(x,-1)=0$

$i i(x, y)=i i(x-1, y)+s(x, y)$,

$i i(-1, y)=0$

با داشــتن تصـوير تجمعى، مىتوان مقدار ويزگىهاى شــبههار را بهسـرعت و با اســفـاده از جمع و تفريق ســاده

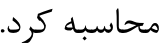

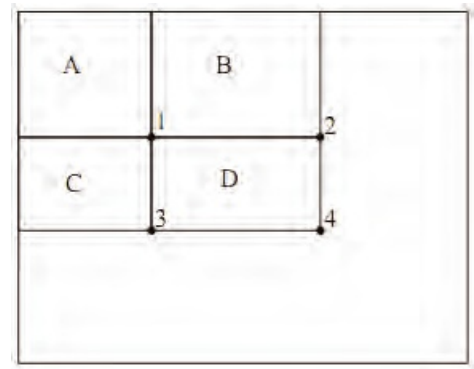

(شكل- ( ): نحوه محاسبه تصوير تجمعى

(Figure- 8): Computing the integral image

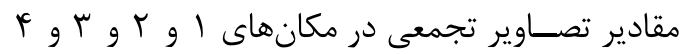
شكل ^ بهصورت معادله (ه) است:

$\mathrm{S}(1)=\mathrm{A} ; \mathrm{S}(2)=\mathrm{A}+\mathrm{B} ; \mathrm{S}(3)=\mathrm{A}+\mathrm{C}$;

$\mathrm{S}(4)=\mathrm{A}+\mathrm{B}+\mathrm{C}+\mathrm{D}$;

در اين صـورت مجموع بيكسلهاى زير مستطيل D بهصورت (9) (9حاسبه خواهد شد:

$\mathrm{D}=[\mathrm{S}(4)+\mathrm{S}(1)]-[\mathrm{S}(2)+\mathrm{S}(3)]$

2 Cumulative Raw Sum

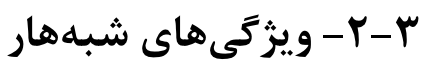

در شكل (ه) يك مجموعه از ويزگى هاى شبههار كه بهعنوان ويزگى هاى ورودى به طبقهبند آبشـارى مورد اسـتفاده قرار

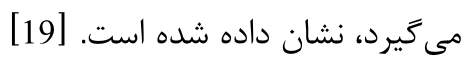

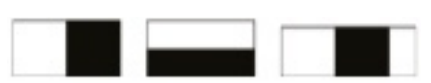

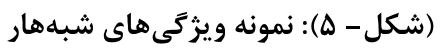

(Figure - 5): Examples of Haar-like features.

مجموع ييكسلهايى كه در زير مسـتطيلهاى سفيد

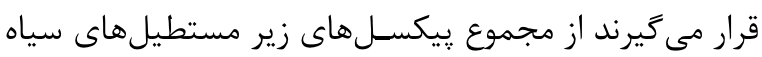

در مقياسهاى مختلف كم مىشـود. اين روش در شـكل (9) نشان داده شده است.

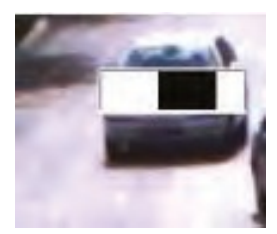

(شكل - 9): بهكاركيرى ويثَى هاى شبه هار بر روى تصاوير خودرو (Figure- 6): Extraction of Haar-like features on vehicle images

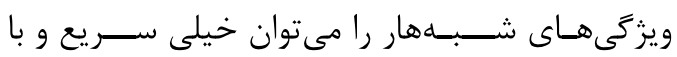

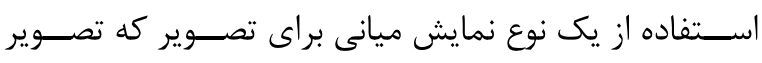

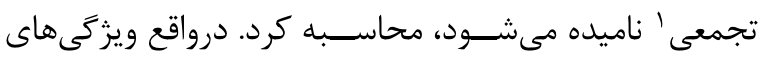

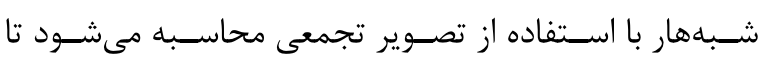
كارايى محاسباتى افزايش يابد.

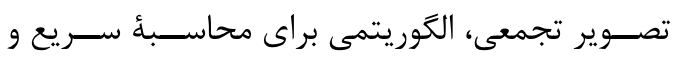
كاراى مجموع مقادير در زيرمجموعههاى مسـتطيلى است. از

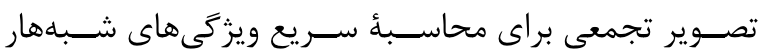
اسـتفاده مىشود. مطابق آنجه در شكل (V) مشاهده مىشود، تصوير تجمعى در نقطة (x, $)$ بالا و در سمت جِّ نقطة ( (广آ) تعريف مىشود.

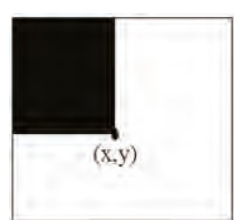

(شكل- (

(Figure- 7): The integral image in point $(x, y)$

\footnotetext{
${ }^{1}$ Integral image
} 
مكانهاى متحرك يس از اعمال مورفولوزى مشاهده مىشود

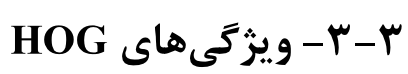

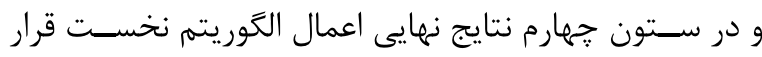

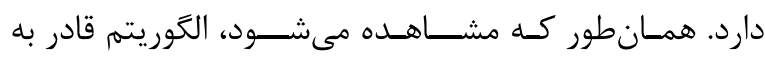
آشـكارسـازى صسحيح خودروها شده است؛ البته در مواردى، برخى از مناطق بهاشتباه خودرو تشخيص داده شده است؛ اما

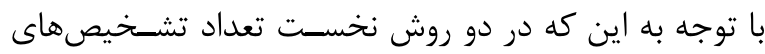

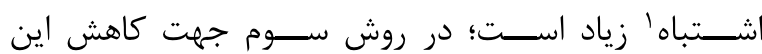
تشـخيصهاى اشـتباه از يك طبقلهبند SVM اسـتفاده شــده اسـت. بدين ترتيب كه پِ از اسـتخراج تصـاوير خودروها با

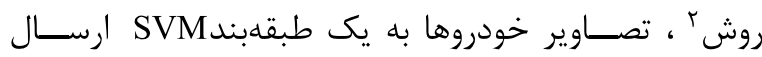

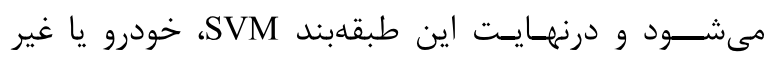

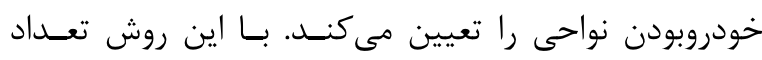
تشـخيصهاى اشـتباه تا حدى كاهش مىيابد. در جدول (1) نتايج اعمال اين سه الكَوريتم مشاهده مىشود. با بررسـى نتايج جدول (1) مشــاهده مىشــود كه

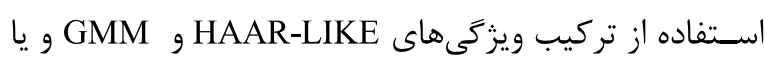
نســـــت بـهـ زمانى كه از GMM و GOG نمىشـود، نتايج بهترى ازلحاظ سـرعت و دقت يردازش دارد.

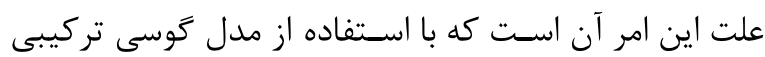
ابتدا مناطق متحرك شناسايى شده و درنتيجه آشكارساز تنها

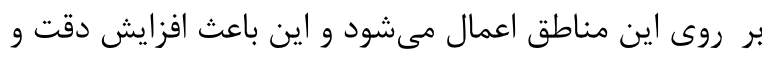

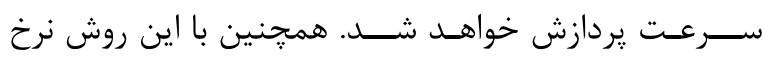

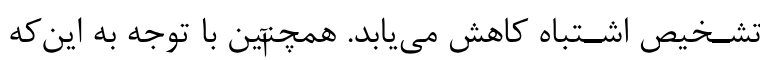

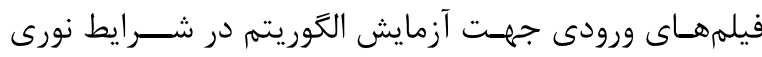
مختلف فيلهبردارى شــده اســت، و از نجايى كه ويزگى هاى

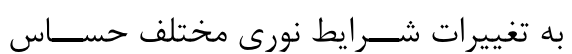
HOG

نيستند. استفاده از ويزَّىهاى HOG و طبقلبند Ada-boost نتايج بهترى ازلحاظ دقت بردازش نســبت به دو روش ديخر خواهد داشـــ؛ و درصـــورتى كه از طبقهبند SVM در كر كنار Ada-boost يافت؛ اما اين باعث افزايش زمان اجراى الكَوريتم خواهد شد.

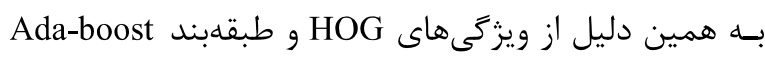
جهت آشكارسازى خودروها استفاده مىشود.

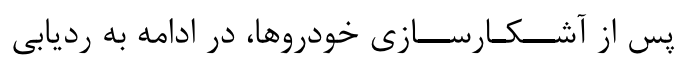
خودروهاى حاضر در صحنه خواهيم يرداخت.

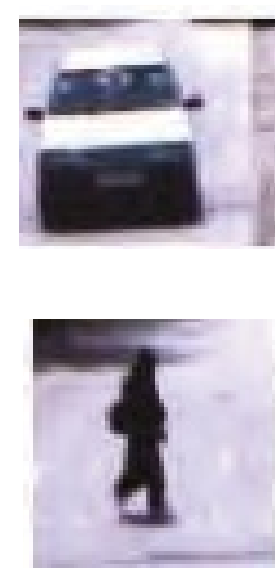

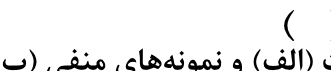

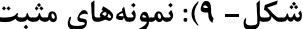

(Figure- 9): (a) Positive images; (b) negative images

\section{ץ-F - نتايج اعمال الخوريتهمهاى آشكارسازى}

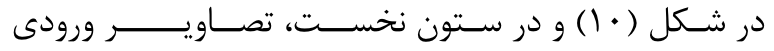
الكَوريتم نشـان داده شـده است ـ در ستون دوم با استفاده از

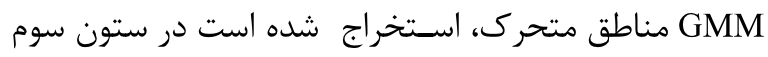

1 False Alarm

2 Deterministic Methods for Correspondence 


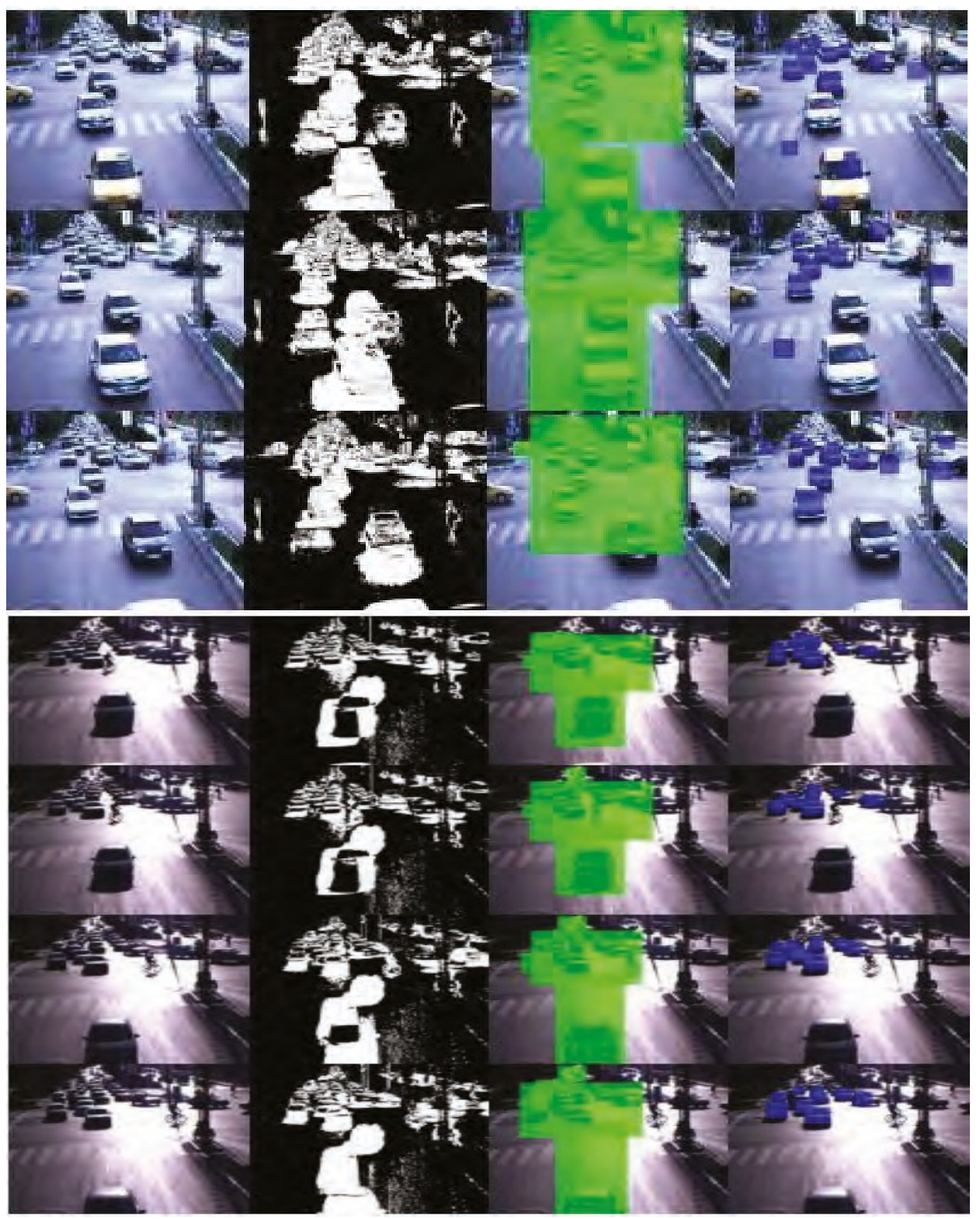

(شكل- • (1): نتايج اعمال الگوريتم آشكارسازى بر روى فيلمها با شرايط نورى مختلف

(Figure- 10): The results after applying the detection algorithm on films with different illumination conditions

(جدول - (): نتايج اعمال الكوريتمهاى آشكارسازى

(Table-1): The detection algorithms results

\begin{tabular}{|c|c|c|c|c|c|c|}
\hline 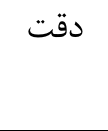 & زمان اجرا & تشخيص اشتباه & نادرست (Miss) & |تشخيص درست & تعداد كل & روش آشكارسازى خودرو \\
\hline$\wedge 9, \cdot 1$ & $1, \cdot V$ & rl. & $1 \wedge V$ & $19 V \pi$ & $1 \wedge 9$. & Haar-like \\
\hline$q \cdot, \cdots$ & $\cdot, V \Delta$ & ITF & IV9 & $19 \Lambda F$ & $1 \wedge 9$. & GMM + Haar like \\
\hline $9 \cdot, \cdots$ & $1, \cdot 1$ & $19 V$ & 191 & 1994 & $1 \wedge 9$. & $\mathrm{HOG}+$ Adaboost \\
\hline $9 \cdot, 11$ & 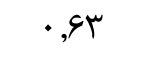 & 111 & 190 & 1990 & $1 \wedge 9$. & $\mathrm{GMM}+\mathrm{HOG}+$ Adaboost \\
\hline $9 \cdot, \wedge \cdot$ & $\cdot, 9 V$ & 19 & $|V|$ & 1919 & ING. & $\mathrm{GMM}+\mathrm{HOG}+\mathrm{SVM}$ \\
\hline
\end{tabular}

${ }^{4}$ Cost Function

${ }^{1}$ Deterministic Methods for Correspondence

${ }^{2}$ Statistical Methods for Correspondence

${ }^{3}$ Proximity 

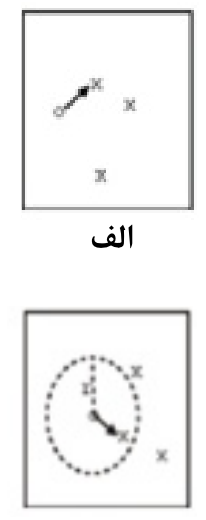

$\varphi$

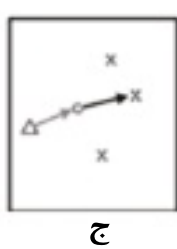

$\tau$

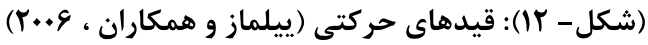

(Figure- 12): Motion Constraints(Yilmaz, Javed, \& Shah, 2006)

يس از تعيين قيدهاى حركتى، تابعى براى ييوســتن هر

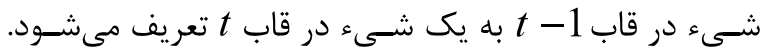

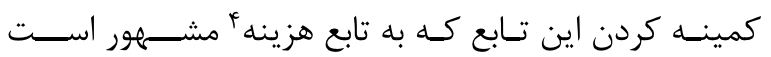

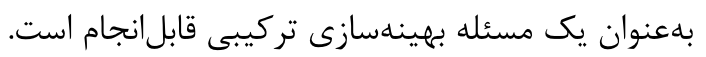

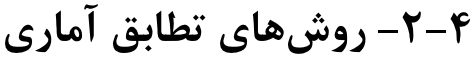

روشهـاى تطـابق آمـارى، از روش فضـــاى حاى حالت براى مدل

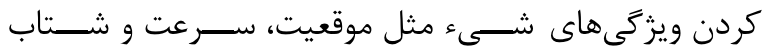

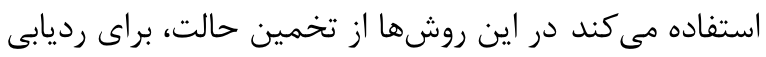

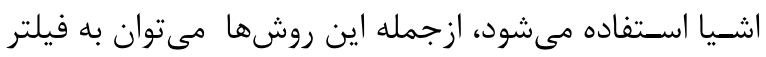
بيز بازگشتى و فيلتر كالمن اشاره كرد.

\section{ه- معرفى الكوريته بيشنههادى}

همانطور كه اشـاره شد، در اين مقاله جهت رديابى خودروها

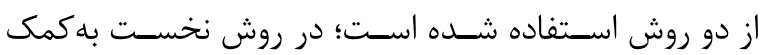

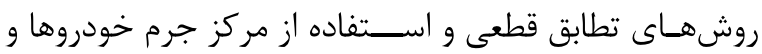

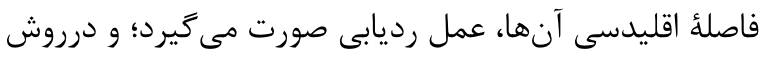

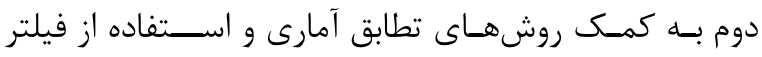
كـالمن' و مركز جرم خودروهـا، عمـل رديابى خودورها انجام

${ }^{1}$ Kalman Filter

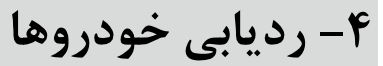

در اين مقـالـه جهـت رديـابى خودروها از روش نمايش نقطه

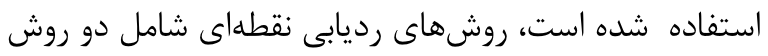

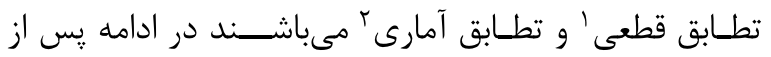

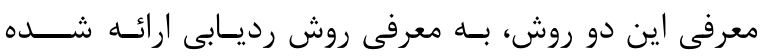

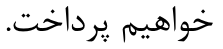
F-1- روشهاى تطابق قطعى

روشهاى مختلف رديابى با توجه به اينكه از جه روشى جهت إنها نمايش اشسيا و يا استخراج ويزگى هاى آنها استفاده مى كنند با يكديكر تفاوت دارند. يكى از روشهاى نمايش اشيا، استفاده از روش نمايش نقطه است، در اين روش يك شىء مى تواند فقط با يك نقطه،

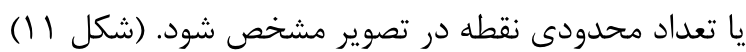
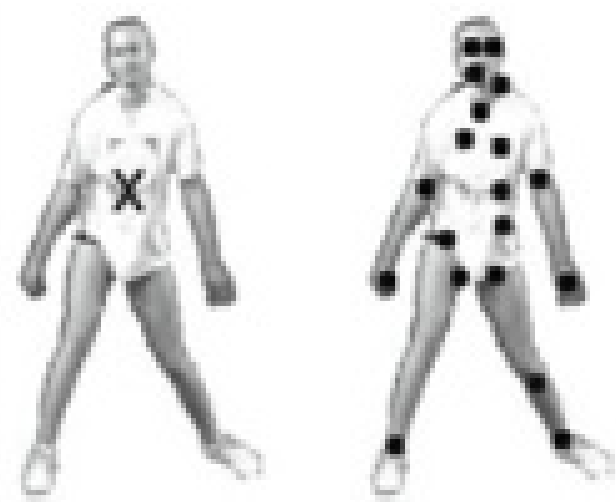

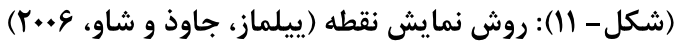
(Figure- 11): Object representations by multiple points (Yilmaz, Javed, \& Shah, 2006)

اكر اشيا را بهصورت نقطه نمايش دهيم، مىتوان كفت

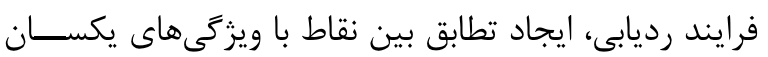

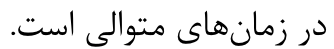
در روشهـاى تطـابق قطعى، يِيش از عمـل رديـابى

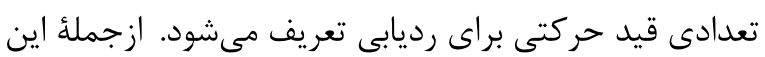

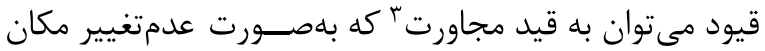

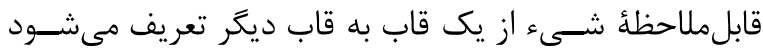

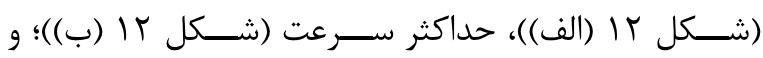

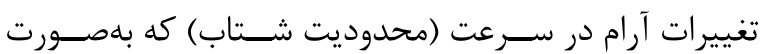
عدمتغيير جهت و سـرعت شىء با شدت زياد تعريف مىشود، (شكل r إ- (ج). اشاره كرد. 
در اين مرحله نيازمند يك روش انتســاب بهينهُ كلى

براى ايجـاد مطابقت بين مراكز خودروها در قابهاى متوالى دئى هستيم. اين بهينكى كلى مىتواند بهصورت تخمين بيشترين

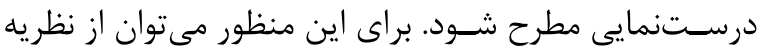

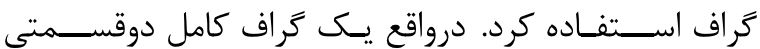

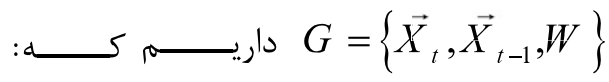

بردار خودروهاى آشكارشده $\vec{X}_{t}=\left\{X_{t}^{i}, i \in 1, \ldots, \mathrm{N}_{t}\right\}$ در زمــان t خودروهاى آشكارشده در زمان 1-1 و و: كـ $W=\left\{W_{t, t-1}^{i, j}, i \in 1, \ldots, \mathrm{N}_{t}, j \in \mathrm{N}_{t-1}\right\}$

درواقع وزن يـالهـاى كراف اســت، شــامـل مجموعه تمام مطابقتهاى فرضى بين نقاط در دو زمان t tو 1-t است. براى محاسبة W ابتدا فاصله اقليدسى تمامى نقاط در

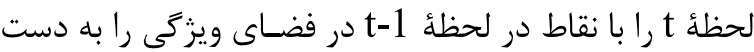

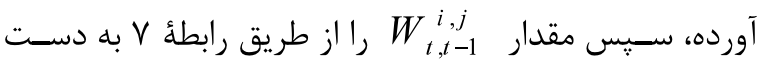

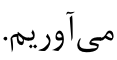

$w_{t, t-1}^{i, j}=\left\{\begin{array}{cc}1-\frac{d_{t, t-1}^{i, j}}{d_{\max }} & d_{t, t-1}^{i, j}<d_{\max } \\ 0 & \text { else }\end{array}\right.$

در اين رابطـهـ ش $j \in \mathrm{N}_{t-1}$

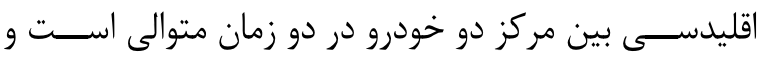
d بيشينه جابهجايى است كه يك خودرو مىتواند داشته بـاشـــد. بـا اين رابطـهـ خودروهاى نزديكتر وزن بيشــترى

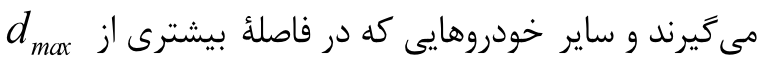
هســتــد، وزن صــفر خواهند گرفت. بهاينترتيب مىتوان

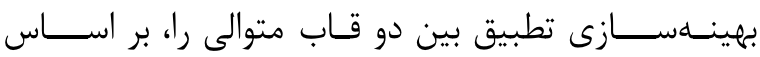
بيشـينهكردن اين تابع وزنى انجام داد. بهترين تطبيق در اين كَراف وزندار، تطبيقى بـا بيشترين وزن از ميـان تمـام تطبيقهاى ممكن اسـت. با وجود وزنهاى W كه بر اسـاس رابطؤ \ تعريف شدهاند، تطابق بهينهُ كلى بين دو مجموعه از خودروها با بيداكردن بيشترين تطبيق در G بهدست مى آيد.

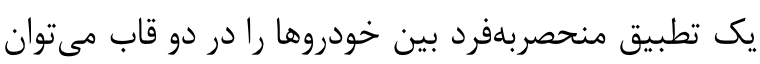
بلبورت رابطة \ متعريف كرد:
روندنماى روش نخست در شكل (با) مشاهده مىشود. در ادامه به معرفى مراحل الكَوريتم پِيشنهادى

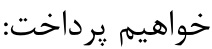

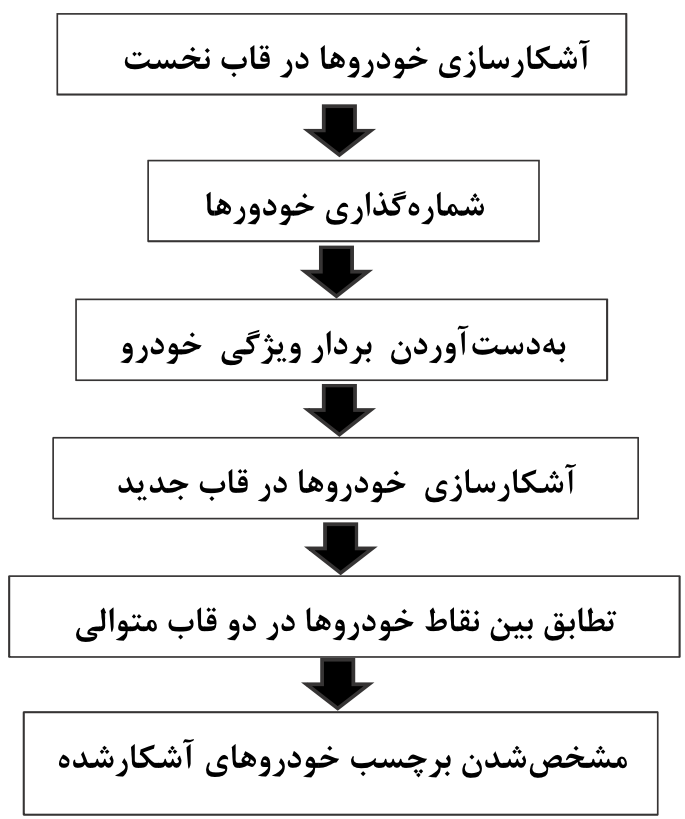

(شكل - با): روندنماى رديابى خودرو

(Figure- 13): Flowchart of tracking the targets

در مرحله نخست، آشكارسازى خودروها به كمك يكى از روشهاى آشـارسازى، صورت مى گيرد؛ سيس به هركدام

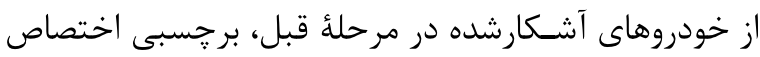
داده و بردار ويزگى هر خودروى برجسب گَذارى شده محاسبه

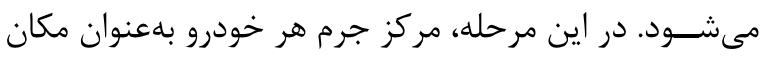
$\overrightarrow{\boldsymbol{X}}_{0} \equiv\left\{X_{0}^{i}, i=1, \ldots, N_{0}\right\}$ آن در زمسان

ذخيره مىشود. در اين بردار N تعداد خودروها و و 程 $\chi_{0}^{i}=\left(x_{0}^{i}, y_{0}^{i}\right)$ همجنين علاوهبر مركز جرم، اندازٔ طول و عرض و مختصـات يكى از گَوشهها (در اينجا: كَشه جِّ/ بالايى) ، بهعنوان بردار ويزگى هر خودرو ذخيره مىشود.

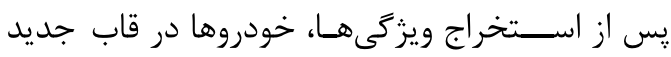
آشـكارسازى شده و مركز ثقل آنها را در بردار مكان خودرو در زمان =0 ذخيره مىشود. در مرحله بعد كه نه مهرمترين بخش الكوريتم اســت، بـايد عمل تطابق بين نقاط موجود در بردارها، جهت رديابى خودروها صورت گيرد. 
$\left\{\begin{aligned} X_{t}^{i} & =X_{t-1}^{i}+\bar{d}_{x, t-1} \\ y_{t}^{i} & =y_{t-1}^{i}+\bar{d}_{x, t-1}\end{aligned}\right.$

بــأرتيـب ميـانغين جـابهجايى خودرو در $\bar{d}_{x, t-1} \bar{d}_{y, t}$

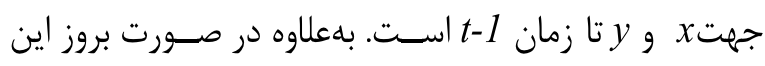

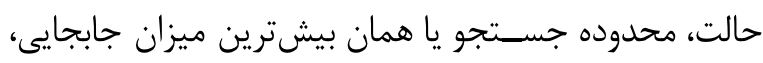

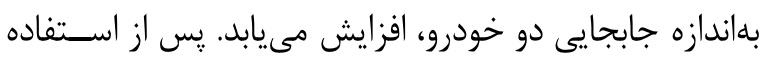
از اين روش مشـاهده شـد كه اين روش در مواقعى كه تعداد

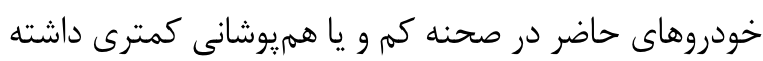

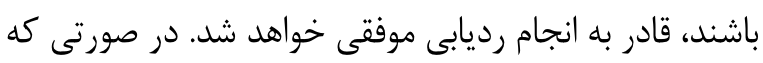

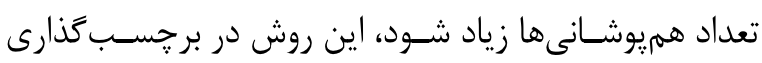
خودروها و درنتيجه در رديابى آنها روش موفقى نخواهد بود؛

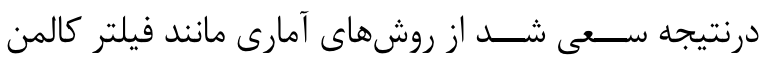
براى تخمين محل جديد خودروها اسـتفاده شـود. روشهاى

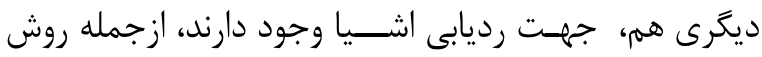

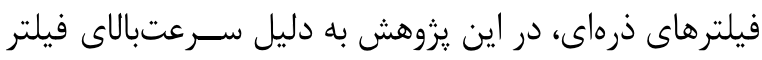

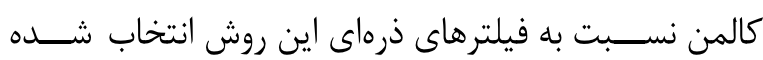

براى اســتفــاده از فيلتر كـالمن، يس از اختصـــاص برجسـب به خودروها، براى هر خودرو يك فيلتر كالمن ايجاد كرده و مركز جرم خودروها به فيلتر كالمن ارسـال مىشــود.

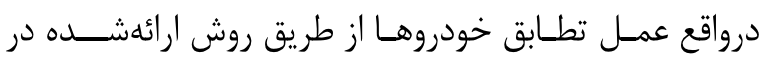

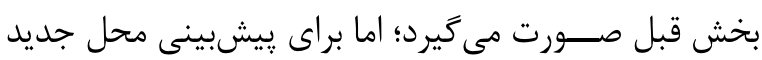

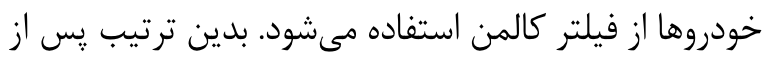

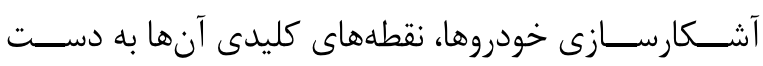

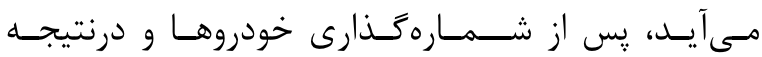
مشـخصشـدن برجسـب خودروها، تطبيق نقاط بين دو قاب

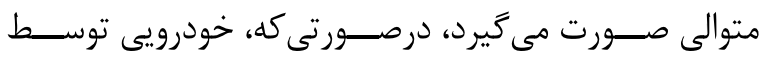

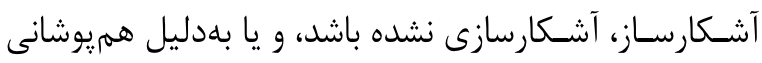

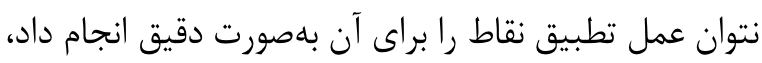

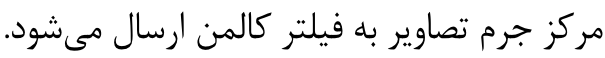
در فيلتر كالمن كه يك پِالائ بازَشتى كاراست حالت يك سـامانٔ يويا از دنبالهاى از سنجشهاى ناقص و مخدوش تخمين زده مىشود [23]
$M=\underset{M \in H}{\arg \max } \sum W\left(\overrightarrow{\boldsymbol{X}}_{t}, \overrightarrow{\boldsymbol{X}}_{t-1}\right)$

در رابطـــ بالا H H مجموعه همه تطبيقهاى ممكن در

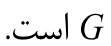

اما روش ييشـنهادى زمانى موفق خواهد بود كه تعداد خودروهاى حاضر درصحنه ثابت باشد، درصورتى كه در صحنه

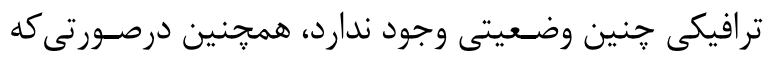
خطاى آشـكارسـازى وجود داشـته باشــد، و يا خودروها با يكديكر هميوشـانى داشـته باشــند، روش بالا قادر به رديابى موفق خودروها نخواهد شـد. اما براى غلبه بر سـه مشكل بالا ملاحظاتى را به الكوريتم رديابى خود اضافه خواهيم كرد:

\section{الف) ورود و خروج خودروها از صحنه} در صورت ورود خودرويى جديد و آشكارسازى آن، در بخش كنترل ورود خودرو جـديسد بسه تصــوير، يس از ايجاد

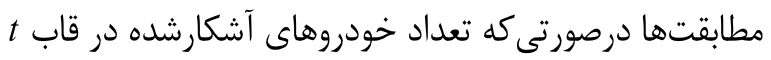
بيش از قاب t-1 باشـــد به هركدام از عناصــر باقىمانده يك ديك

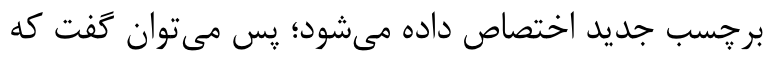

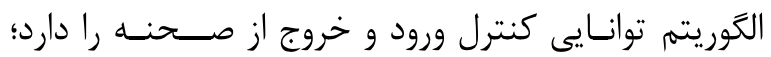
درنتيجه بيرون رفتن خودروها از صـــنه مشــكلى را ايجاد

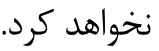

\section{ب) خ خطاى آشكارسازى} با توجه به اينكه برجسـب خودروها و مركز ثقل آنها در بردارى ذخيره مىشـود، درصـورتى كه در يك يا جند قاب

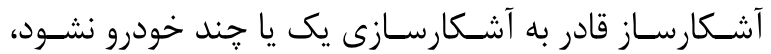

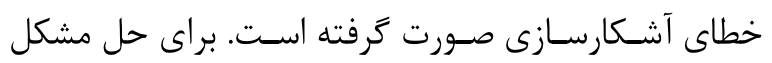
رديابى در جنين حالاتى محل خودرو تخمين زده مىشــود، و و محل تخمينزدهشده، بهعنوان محل خودرويى كه در آن قاب توسط آشـكارساز مشخص نشده، در نظر ترفته مىشوده. اما براى تخمين محل خودرو از ميانكَين جابهجايىهاى كذشسته

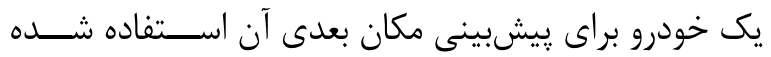

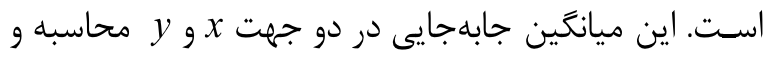

به مختصات نقطه در قاب قبلى اضافه مىشود. (رابطهُ 9) 
همجنين در شكل (Q (1) در قاب Y Tr آشكارساز قادر به

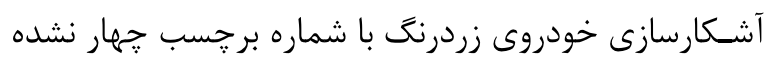

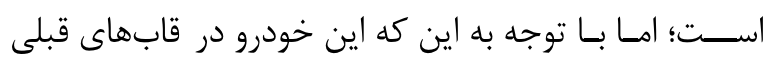

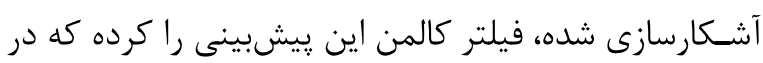

آن مكان بايد خودروى با شـماره بر جسب جهار آندار وجود داشته

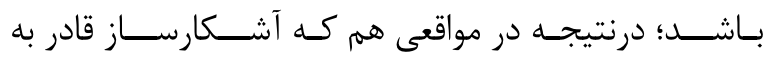

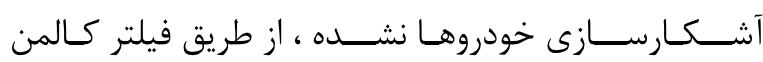

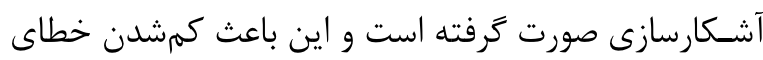
آشـكارسـازى هم شده است. البته ممكن است كه خودرو در

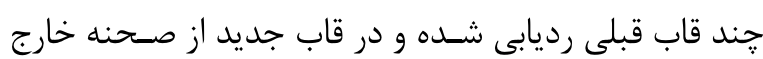

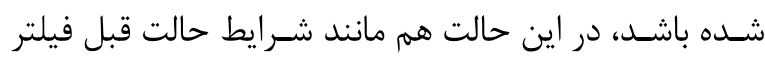

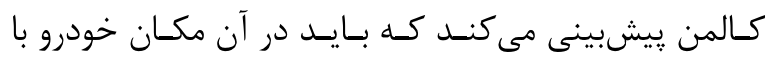

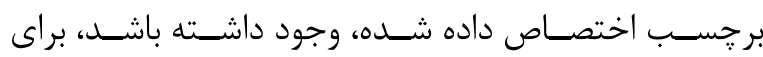
جلو

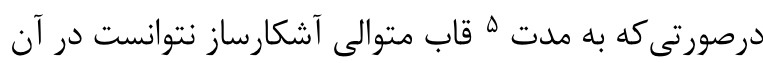

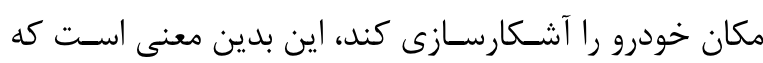

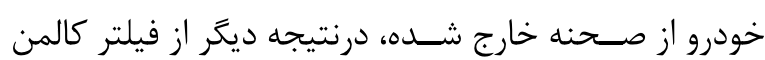

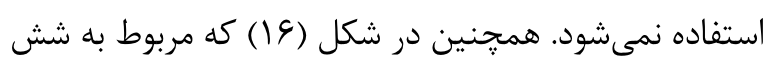

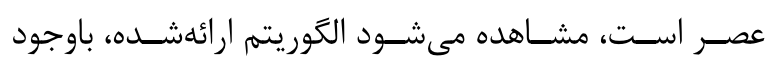
تغييرات شـرايط نورى قادر به آشكارسازى و رديابى خودروها

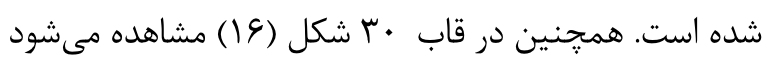

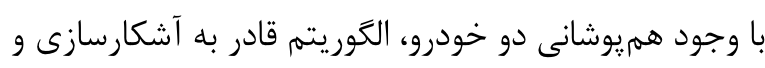

$$
\text { رديابى آنها شده است. }
$$

جهت ارزيابى الكوريتم ارائهشسه از معيار

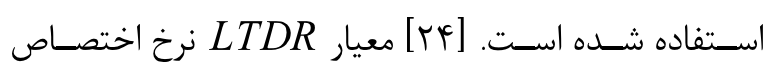
برجسـبـهاى صـحيح منحصـربهفرد به خودروها را تعيين

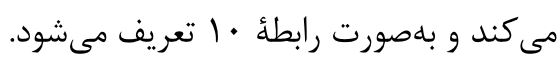

$L T D R=\frac{1}{L} \sum_{i=o}^{L-1} \frac{T P M_{i}}{O A F_{i}}$
بنـابراين فرمولهـاى فيلتر كـالمن را مىتوان در دو كروه دسـتهبندى كرد: معادلات بهروزرسـانى زمان' (معادلات

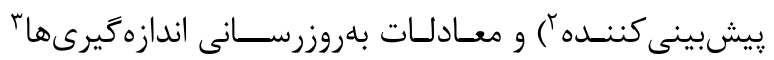

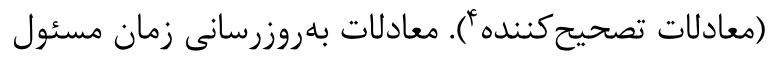
تأمين روبهجلوى (در زمان) حالت جارى و تخمين كوواريانس خطا بهمنظور به دسـت آوردن يك تخمين اوليهه براى تام

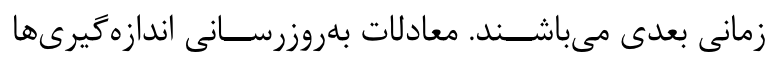

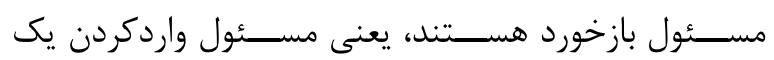

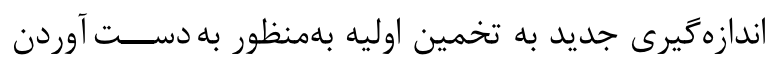

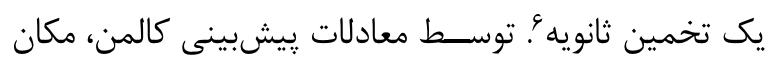
جديد خودرو بيشبينىشــــه و در قاب بعدى بس از از تعيين مكان اصسلى خودرو، توسـط معادلات تصسحيح اندازمخيرىها بكروزرسانى مىشود.

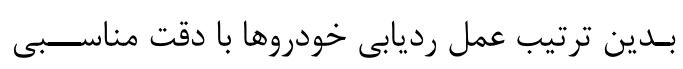

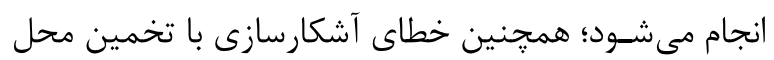

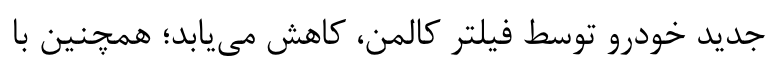

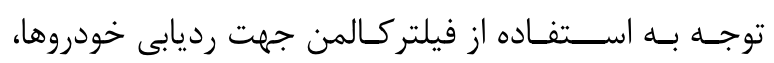
سرعت الكوريتم در شرايط ناموفق دجار مشكل نخواهد شد.

\section{ه-1- ييادهسازى و ارزيابى روش پيشنههادى}

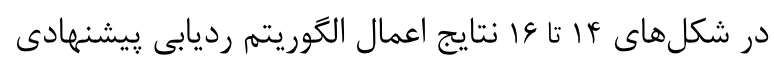

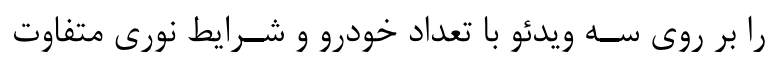
مشاهده مىشود. در شـكل (f ( )، در شـروع تعداد خودروهاى متحرى

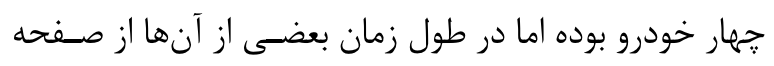

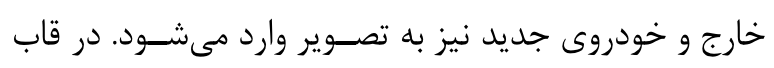

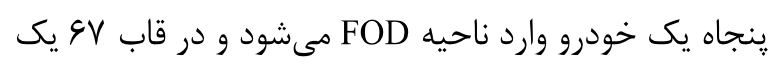

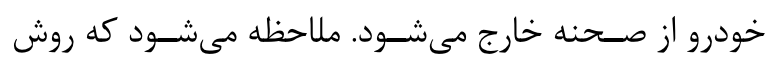
بيشنهادى توانايى مديريت اين اتفاق را دارد.

\footnotetext{
${ }^{1}$ Time update

${ }^{2}$ Predictor

${ }^{3}$ Measurement update

${ }^{4}$ Corrector

5 Priori

6 Posteriori

7 Label Tracking Detection Rate
} 
درسـت عمـل كرده اســت. در جدول دو نتايج حاصــل از

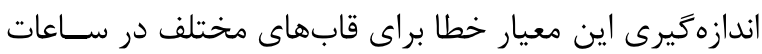

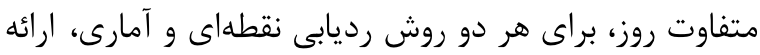

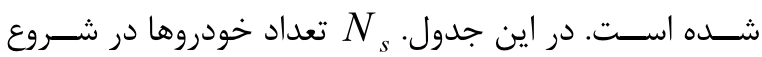

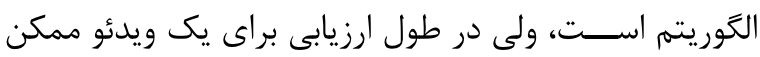

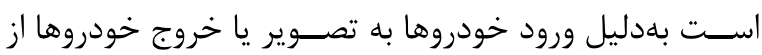

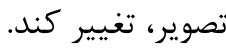

در اين رابطـهـ L تعـداد كـل خودروهـايى اسـتـ كه بايد

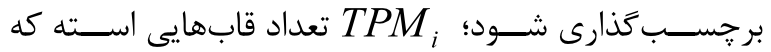

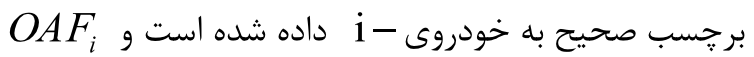

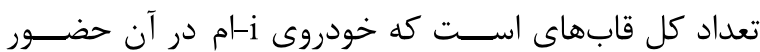
داشته است.

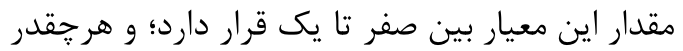
به يك نزديكتر باشد، به اين معنى است كه الكوريته رديابى ونى
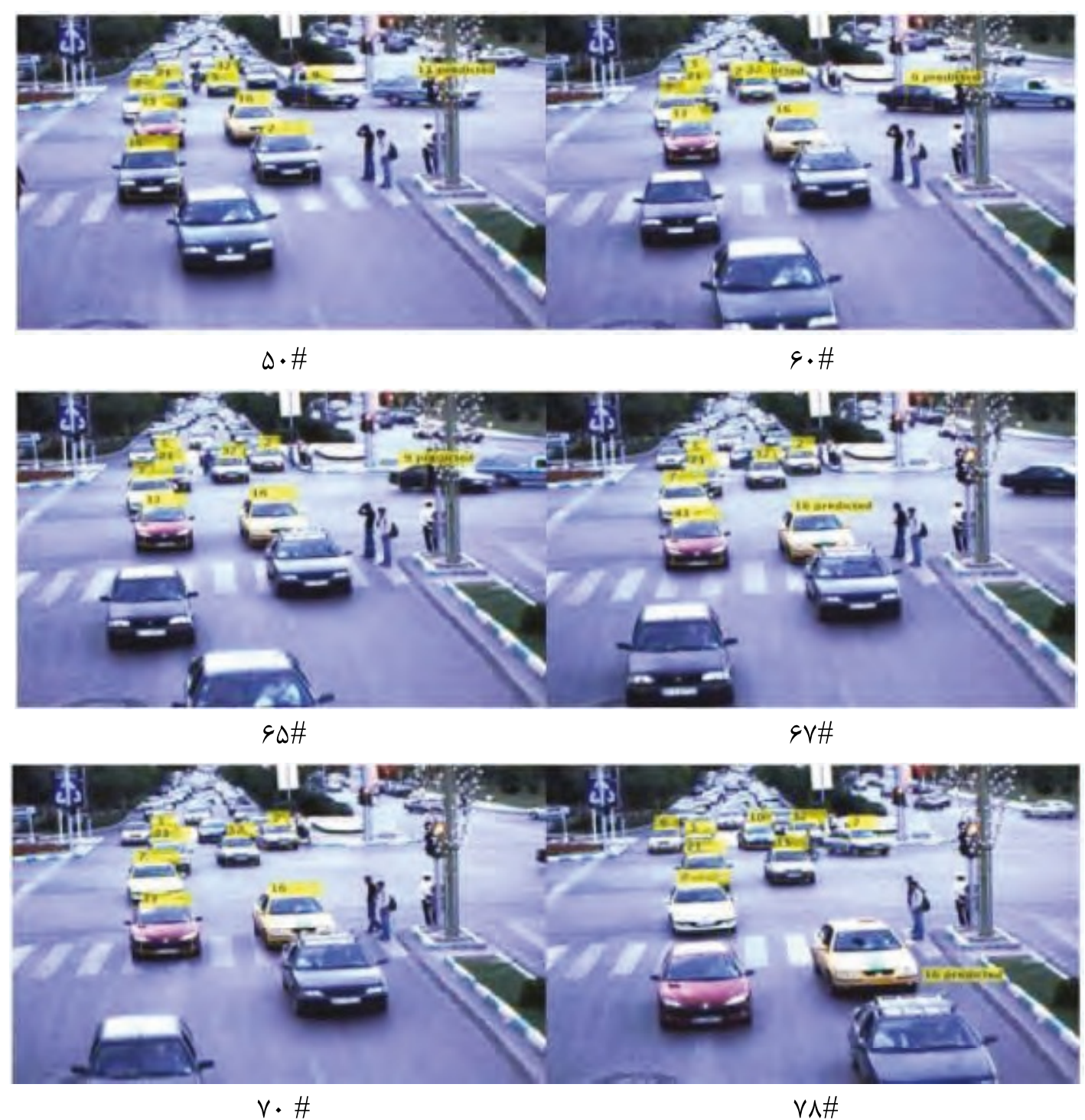

(شكل - f(): نتايج استفاده از الكوريتم پييشنهادى در قابهاى مربوط به ساعت 9 صبح AM (Figure- 14): The proposed algorithm results in the frames of 9 

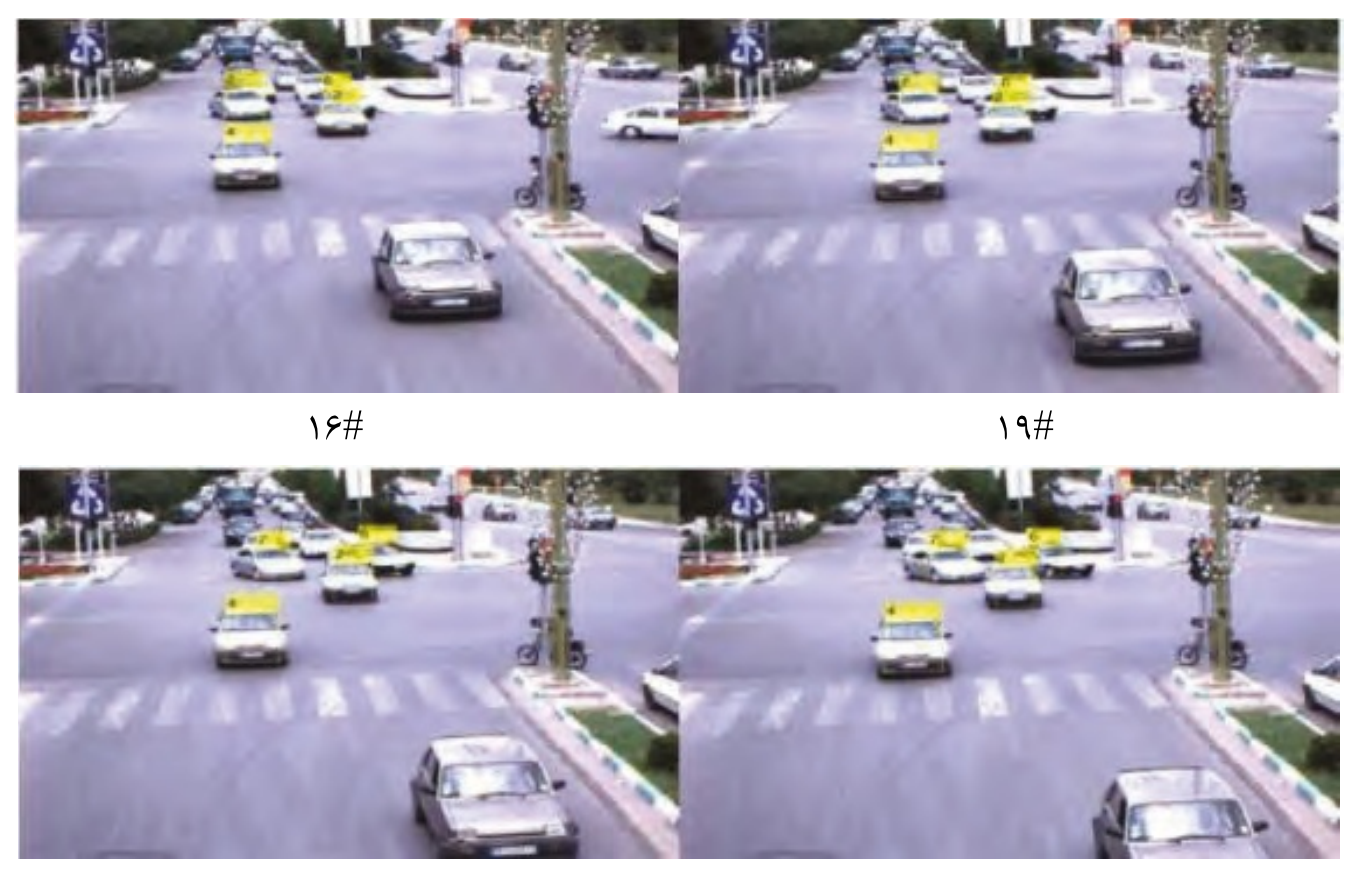

Tr\#

ro \#

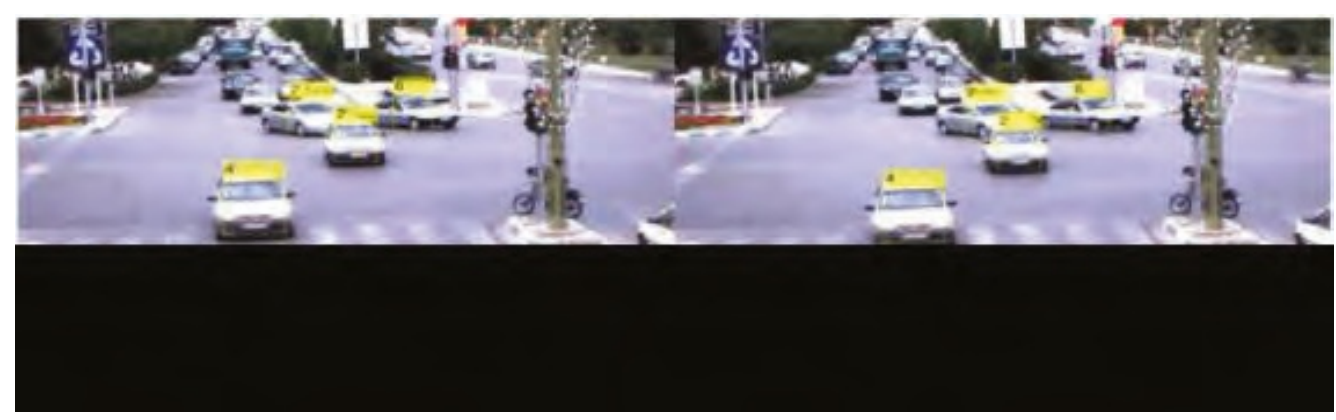

「ᄉ\#

ए”

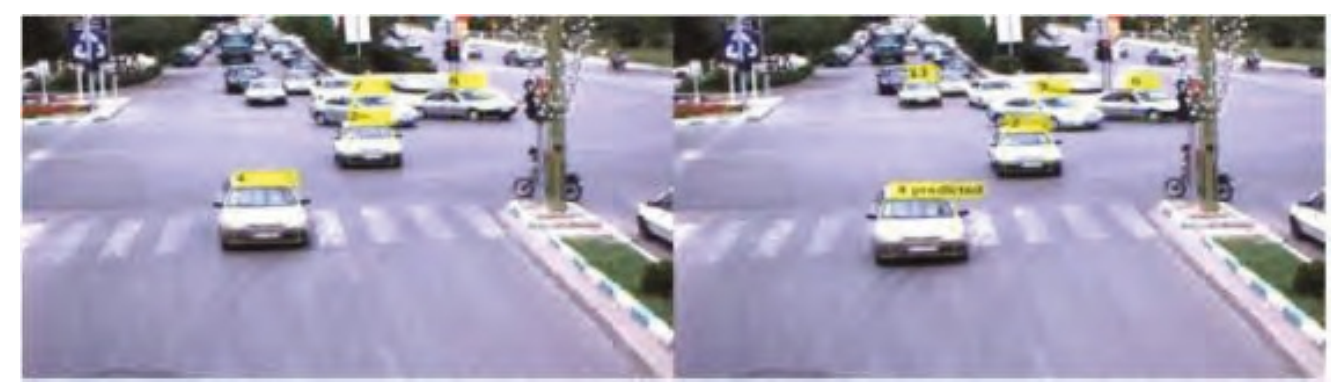

ry \#

rV\#

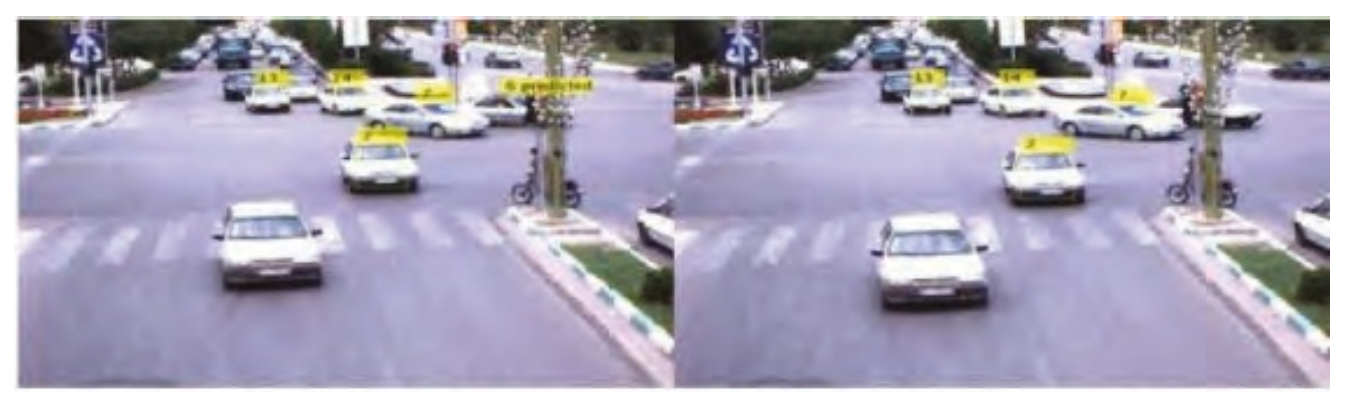

$r \cdot \#$

FrH

(شكل- 1ه): نتايج استفاده از الكَوريته بيشنهادى در قابهاى مربوط به ساعت זا ظهر

AM (Figure-15): The proposed algorithm results in the frames of 12 


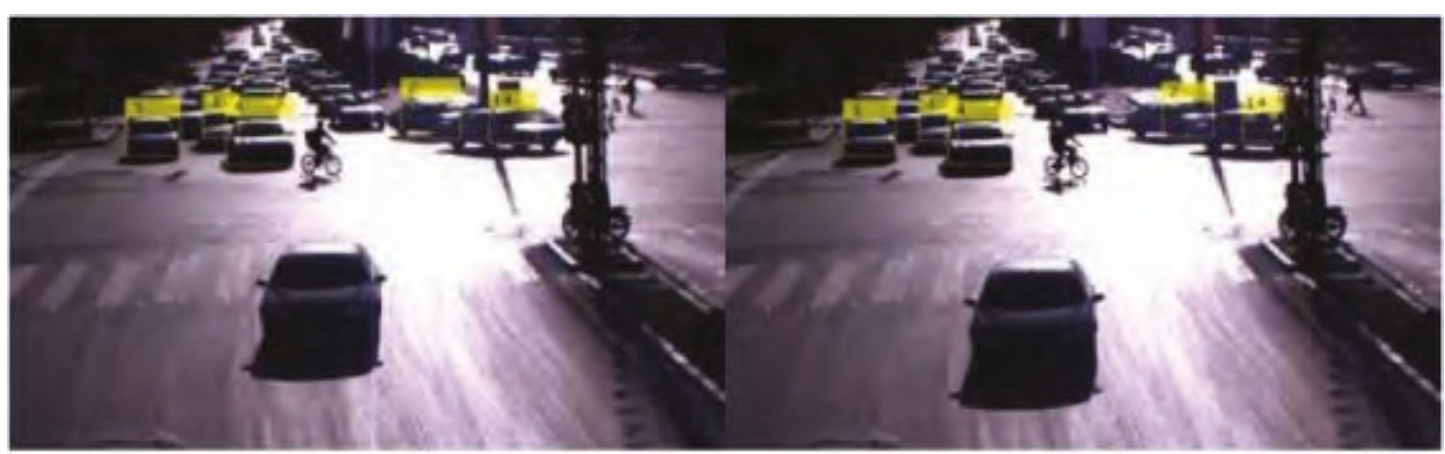

rr\#

r\&\#

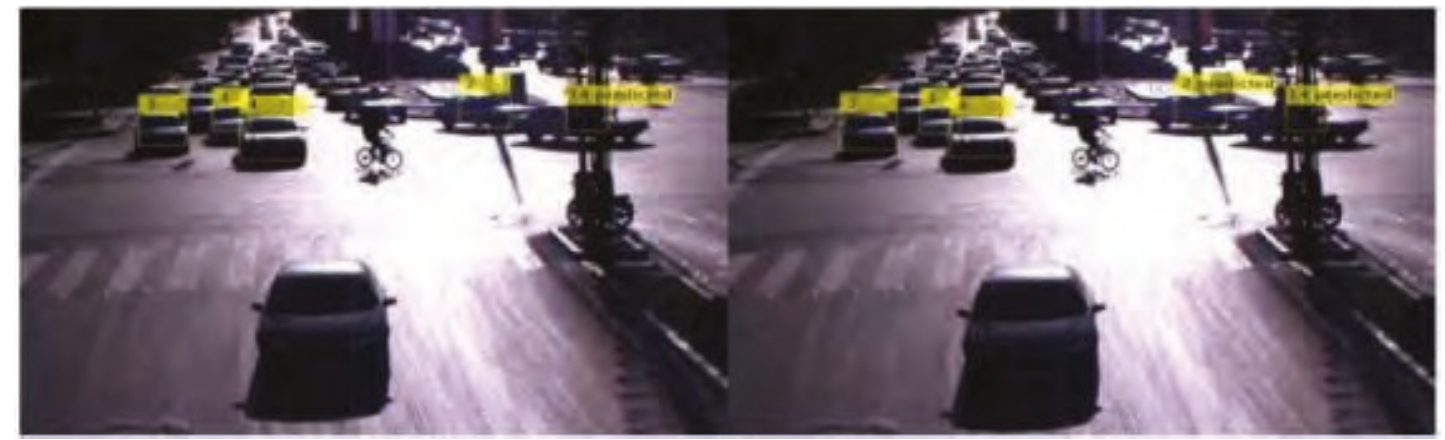

rq\#

$\mu \cdot \#$

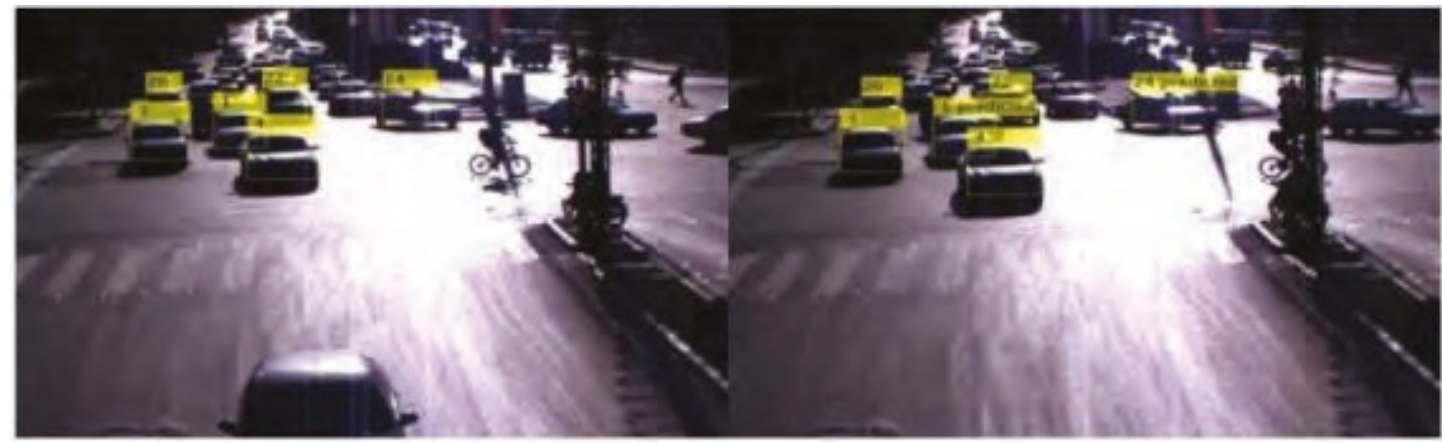

(i) \#

FA \#

(شكل- 19): نتايج استفاده از الكَوريتم بِيشنهادى در قابهاى مربوط به ساعت 9 عصر

PM (Figure-16): The proposed algorithm results in the frames of 18

خودروها ايجاد درخشـــندى مى شـــود و در ســاعت هجده بلهدليل نور كمم و بلندترشـدن سـايهها هر خودرو داراى سايه

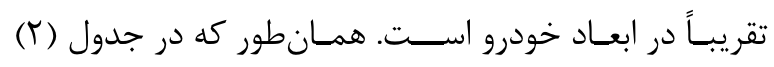
مشاهده مىشود، الخوريتم رديابى ييشنهادى در شرايط نورى مختلف، قادر به رديابى موفق خودروها شـده است. همجنين

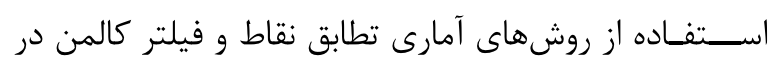
مقايســه با روشهاى قطعى در رديابى داراى نتايج بهترى از از

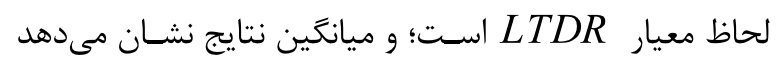
كه با معيار

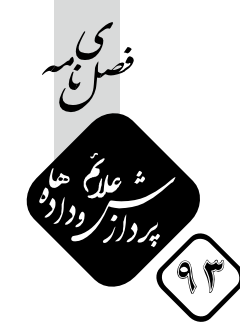

در اين جدول فيلمهاى يك و دو مربوط به ساعتهاى 9 تا || مىباشند، در ساعت 9 صبح تعداد خودروهاى عبورى از تقاطع زياد اسـت، درنتيجه هميوشانى بين خودروها بيشتر مىشــود. با مقايســـ نتايج جدول (Y) مشــاهده مىشــود در فيلمهــاى يكى و دو كه هميوشـــانى بيشـــتر خودروها وجود داشته، روش دوم قادر به رديابى موفق خودروها شده است. فيلم ســه مربوط به سـاعت دوازده ظهر و فيلم تههار IV مربوط به ساعت هجده است. همانطور كه در شكلهاى و 11 ) مشـاهده مىشـود ساعتهاى دوازده و هجده از لحاظ شـرايط نورى جزو بدترين شـرايط هسـتند، زيرا در سـاعت دوازده بهعلت تابش مســتقيم خورشـيد در شــيشــه و بدنه 
f مشـاهده مىشـود. همانطور كه مشاهده مىشود، بالاترين

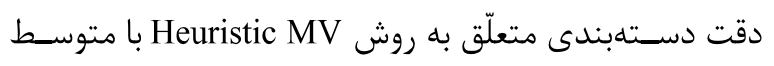

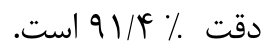

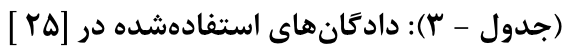

(Table-3): Dataset using in [25]

\begin{tabular}{|c|c|c|c|}
\hline ديتاست & خداد تصاوير| & غير خوداد تصاوير & منبع \\
\hline آموزشى & 1154 & 1154 & CALLTECH2001 \\
\hline آزمايشى & 120 & 180 & $\begin{array}{c}\text { GRAZ + INRIA + the } \\
\text { images }\end{array}$ \\
\hline
\end{tabular}
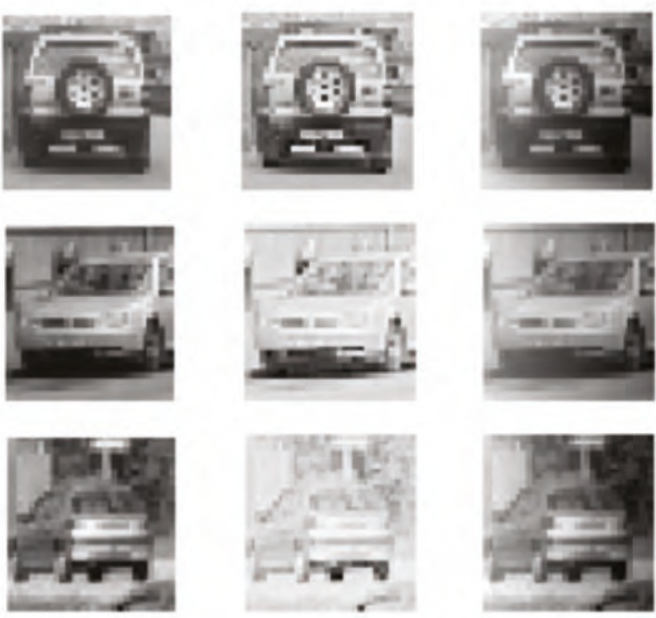

(شكل - IV): تصاوير نمونه با وضوح rFXr. تصاوير اصلى؛ ستون دوم: تصاوير اشباع، سفيدشدهُ تصاوير

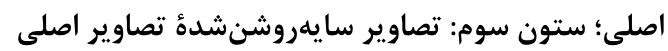
pixel image samples. In the left column, r r Y r r (Figure-17): some validation samples under normal condition; in the middle and right columns, the respective images under penumbra and [25].white saturation

(جدول-f) (ج) دقت دستدبندى روى دادَان تست

(Table-4): Classification accuracy of the method on test DATA

\begin{tabular}{|c|c|c|c|c|}
\hline \multicolumn{5}{|c|}{ [25] } \\
\hline دستابند & نرمال (.) & سايهروشن & سفيد (./) & دتوسط \\
\hline LRF/MLP & 87 & 88 & 85.7 & 86.9 \\
\hline LRF/SVM & 90 & 90 & 83.7 & 87.9 \\
\hline $\mathrm{HOG} / \mathrm{SVM}$ & 92 & 87 & 84.3 & 84.76 \\
\hline Heuristic MV & 94.3 & 91.7 & 88.3 & 91.14 \\
\hline
\end{tabular}

${ }^{2}$ white saturation
(جدول - Y): نتايج رديابى جند خودرو با مركز جرم و فيلتر كالمن

(Table-2): the results of tracking multiple targets with the center of mass and the Kalman Filter

\begin{tabular}{|c|c|c|c|c|}
\hline شماره فيلم & Ns & $\mathrm{L}$ & $\begin{array}{l}\text { LTDR } \\
\text { روش }\end{array}$ & $\begin{array}{l}\text { LTDR } \\
\text { روش r }\end{array}$ \\
\hline 1 & r & 1 . & 0.64 & 0.88 \\
\hline$r$ & $\Delta$ & IV & 0.69 & 0.86 \\
\hline r & f & 9 & 0.72 & 0.89 \\
\hline f & $r$ & 11 & 0.76 & 0.92 \\
\hline \multicolumn{3}{|c|}{ ميانگين } & 70.25 & 88.75 \\
\hline
\end{tabular}

ه-r- مقايســه روش زيشــنهادى با روشهاى

\section{ديخر}

بلمنظور سنجش بيشتر ميزان كارايى روش پيشنهادى، نتايج

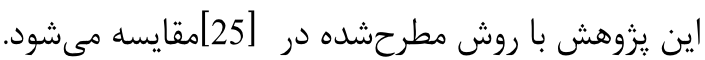
دادخـان بــكـاررفتـه در اين مقـاله در جدول (با) مشـــاهده

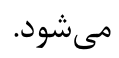

بسهور خلاصسـه در مرجع [25] تركيب ويزّكىهاى HOG و

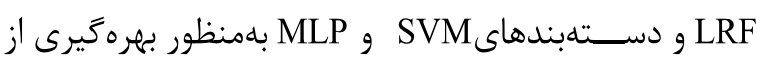

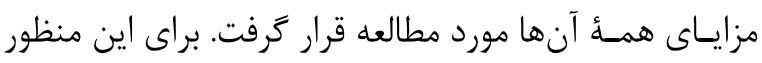
دو روش ييشــنهاد شــدند: روش نخسـت اسـتفاده از الحاق بردارهاى ويزگى است كه نسبت به روش دوم كارايى كمترى از خود نشـان داد. روش دوم استفاده از معمارى دستهجمعى لئى اسـت. در اين روش ويزگىىهاى LRF يكبار توسط دستهبند MLP و بار ديخر توسط دستهبندSVM دستهبندى مىشوند

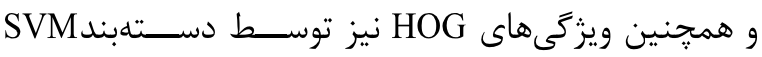

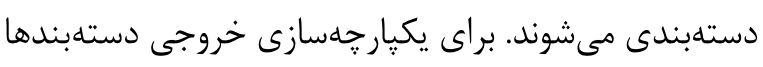
روشهاى مختلفى مورد بررسى قرار گرفتند كه البته بهترين

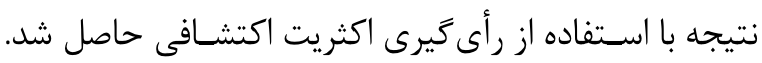

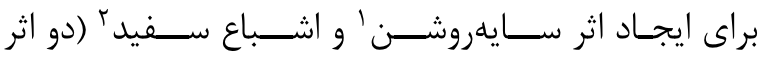

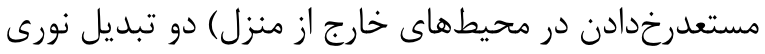

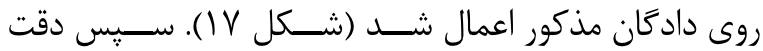
دسـتهبندى روى دادكانهاى سايهروشن و اشباع سفيد علاوه بر دادكان طبيعى محاسـبه شد. نتايج بهدست آمده در جدول دائل

\footnotetext{
${ }^{1}$ Penumbra
} 
خودروى آشـكارشــده در قابهاى متوالى تعريف شـدهاند. با توجه به نوع تابعى كه تعريف شده است به خودروهايى كه در

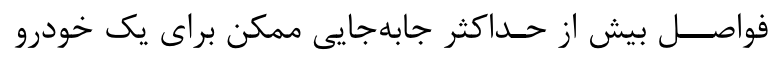

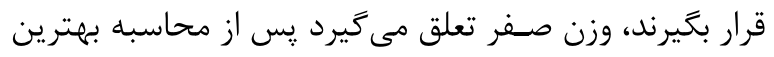

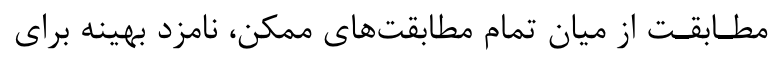

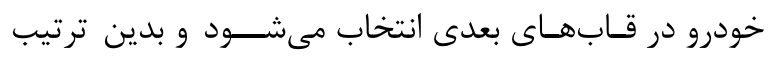

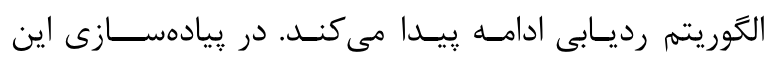

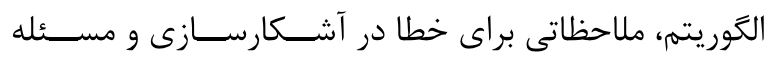
هميوشـانى نيز در نظر كرفته شــد. در ادامه با توجه به اينكه روش ارائهشـده بهتنهايى قادر به رديابى صـحيح خودروها در حالتهاى يِيجيده نبوده، از تركيب روش ارائهشــده با فيلتر كالمن براى رديابى خودروها استفاده شد؛ بدين ترتيب كه در زمانهايى كه آشـارسـاز قادر به آشكارسازى خودروها نبوده جهـت تخمين مكان جديد خودرو از فيلتر كالمن اســفادهاد

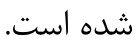
با بررسى نتايج، مشخص شد الخوريتم ارائهشده با دقت NN/VD مختلف در قابهاى متوالى شده است. تقدير و تشكر دراب

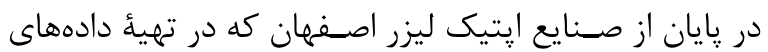
موردنياز مقاله كمال همكارى را كردهاند، تشكر مى كنيه.

\section{7-Reference}

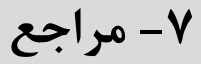

[1] Y. Wu, J. Lim, and M.-H. Yang, "Online object tracking: A benchmark," in Proceedings of the IEEE conference on computer vision and pattern recognition, 2013, pp. 2411-2418.

[2] R. A. Priyadharshini, S. Arivazhagan, and L. Sangeetha, "Vehicle recognition based on Gabor and Log-Gabor transforms," in Advanced Communication Control and Computing Technologies (ICACCCT), 2014 International Conference on, 2014, pp. 12681272.

[3] Y. Zhu, D. Comaniciu, M. Pellkofer, and T. Köhler, "System and method for vehicle detection and tracking." Google Patents, 2010.

[4] D. Balcones, D. F. Llorca, M. A. Sotelo, M. Gavilán, S. Álvarez, I. Parra, and M. Ocaña, "Real-time vision-based vehicle detection for rear-end collision mitigation systems," in Computer Aided Systems Theory-EUROCAST 2009, Springer, 2009, pp. 320-325.
روش קيشــنهادى خود را بر روى اين دادكان اعمال كرديم.

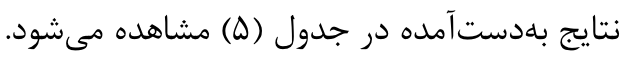

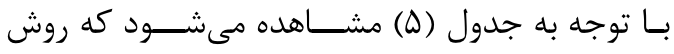
ييشـنهادى اين يزوهش دقت دسـتهبندى را نسـبت به روش Heuristic MV

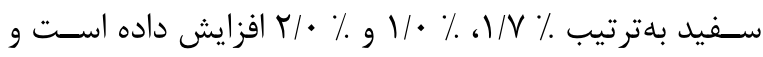

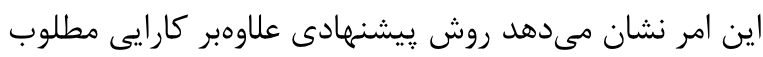
روى تصاوير طبيعى، در برابر وجود نوفه در تصاوير نيز كارايى

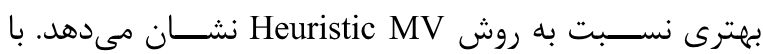

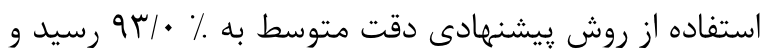
يـا بـهبـارتديخر \% ا ا نســــت به روش Heuristic MV

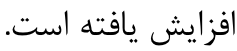

\section{(جدول - ه): دقت دستهبندى روش بيشنهادى بر روى دادكان مشابه}

(Table-5): Classification accuracy of the method on similar data

\begin{tabular}{|c|c|c|c|c|}
\hline دستهبند & نرمال (./) & سايهروشن & |شفيد (./) & دقتوسط (.) \\
\hline بيشنهادى روش & 96 & 92.7 & 90.3 & 93 \\
\hline
\end{tabular}

\section{9- 9تيجهد}

يكى از جالشهاى مهم در آشكارسازى و رديابى خودروها در

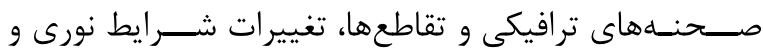

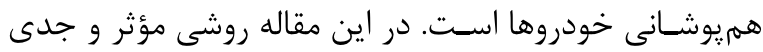
جهت رديابى خودروها در شـــرايط نورى مختلف ارائه شــده اسـت. در اين روش ابتدا تعدادى نقطة كليدى بر روى تصوير

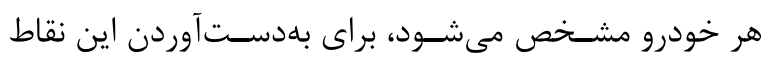

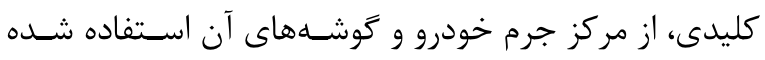

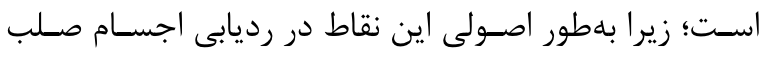

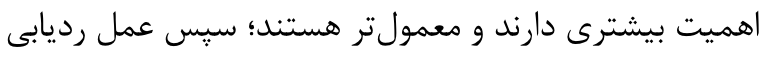

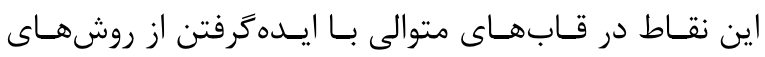
تطبيق قطعى صـورت كرفته اســ؛ در اين روش بر اسـاس

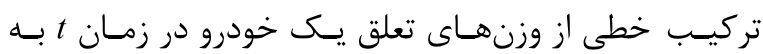

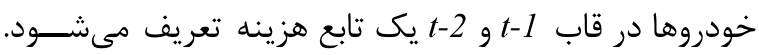

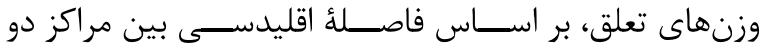


Combined Contourlet Transform with Frame Difference in Highways Surveillance Video," in Advances in Electrical Engineering and Electrical Machines, Springer, 2011, pp. 6571.

[16] C.-C. Wong, W.-C. Siu, P. Jennings, S. Barnes, and B. Fong, "A smart moving vehicle detection system using motion vectors and generic line features," Consum. Electron. IEEE Trans., vol. 61, no. 3, pp. 384-392, 2015.

[17] Z. Sun, G. Bebis, and R. Miller, "On-road vehicle detection: A review," Pattern Anal. Mach. Intell. IEEE Trans., vol. 28, no. 5, pp. 694-711, 2006.

[18] H.-H. Lin, J.-H. Chuang, and T.-L. Liu, "Regularized background adaptation: a novel learning rate control scheme for Gaussian mixture modeling," Image Process. IEEE Trans., vol. 20, no. 3, pp. 822-836, 2011.

[19] P. Viola and M. Jones, "Rapid object detection using a boosted cascade of simple features," in Computer Vision and Pattern Recognition, 2001. CVPR 2001. Proceedings of the 2001 IEEE Computer Society Conference on, 2001, vol. 1, pp. I-511.

[20] M. Bertozzi, A. Broggi, M. Del Rose, M. Felisa, A. Rakotomamonjy, and F. Suard, "A pedestrian detector using histograms of oriented gradients and a support vector machine classifier," in Intelligent Transportation Systems Conference, 2007. ITSC 2007. IEEE, 2007, pp. 143-148.

[21] H. Tan, B. Yang, and Z. Ma, "Face recognition based on the fusion of global and local HOG features of face images," Comput. Vision, IET, vol. 8, no. 3, pp. 224-234, 2014.

[22] A. Yilmaz, O. Javed, and M. Shah, "Object tracking: A survey," Acm Comput. Surv., vol. 38, no. 4, p. 13, 2006.

[23] S. Shantaiya, K. Verma, and K. Mehta, "Multiple Object Tracking using Kalman Filter and Optical Flow," Eur. J. Adv. Eng. Technol., vol. 2, no. 2, pp. 34-39, 2015.

[24] J. Black, T. Ellis, P. Rosin, and others, "A novel method for video tracking performance evaluation," Proc. IEEE Int. Vis. Surveill. Perform. Eval. Track. Surveill. (VS-PETS 03), pp. 125-132, 2003.

[25] L. Oliveira and U. Nunes, "On integration of features and classifiers for robust vehicle detection," in Intelligent Transportation Systems, 2008. ITSC 2008. 11th International IEEE Conference on, 2008, pp. 414-419.
[5] A. Akula, N. Khanna, R. Ghosh, S. Kumar, A. Das, and H. K. Sardana, "Adaptive contourbased statistical background subtraction method for moving target detection in infrared video sequences," Infrared Phys. Technol., vol. 63, pp. 103-109, 2014.

[6] J. Gleason, A. V Nefian, X. Bouyssounousse, T. Fong, and G. Bebis, "Vehicle detection from aerial imagery," in Robotics and Automation (ICRA), 2011 IEEE International Conference on, 2011, pp. 2065-2070.

[7] B. Tian, Y. Li, B. Li, and D. Wen, "Rear-view vehicle detection and tracking by combining multiple parts for complex urban surveillance," Intell. Transp. Syst. IEEE Trans., vol. 15, no. 2, pp. 597-606, 2014.

[8] J.-Y. Choi, K.-S. Sung, and Y.-K. Yang, "Multiple vehicles detection and tracking based on scale-invariant feature transform," in Intelligent Transportation Systems Conference, 2007. ITSC 2007. IEEE, 2007, pp. 528-533.

[9] J. Ning, L. Zhang, D. Zhang, and W. Yu, "Joint registration and active contour segmentation for object tracking," Circuits Syst. Video Technol. IEEE Trans., vol. 23, no. 9, pp. 1589-1597, 2013.

[10] G. Hu, N. Gans, N. Fitz-Coy, and W. Dixon, "Adaptive homography-based visual servo tracking control via a quaternion formulation," Control Syst. Technol. IEEE Trans., vol. 18, no. 1, pp. 128-135, 2010.

[11] X. Cao, Z. Shi, P. Yan, and X. Li, "Collaborative Kalman filters for vehicle tracking," in Machine Learning for Signal Processing (MLSP), 2011 IEEE International Workshop on, 2011, pp. 1-6.

[12] Y. Liu, Y. Lu, Q. Shi, and J. Ding, "Optical flow based urban road vehicle tracking," in Computational Intelligence and Security (CIS), 2013 9th International Conference on, 2013, pp. 391-395.

[13] J. Kokkala and S. Särkkä, "Combining particle MCMC with Rao-Blackwellized Monte Carlo data association for parameter estimation in multiple target tracking," Digit. Signal Process., vol. 47, pp. 84-95, 2015.

[14] A. Jazayeri, H. Cai, J. Y. Zheng, and M. Tuceryan, "Vehicle detection and tracking in car video based on motion model," Intell. Transp. Syst. IEEE Trans., vol. 12, no. 2, pp. 583-595, 2011.

[15] C. Wang, "Moving Vehicle Detection 
دانشكدة فنى و مهندسى دانشكاه اصفهان است. زمينههاى علمى مورد علاقه ايشان شامل موضوعاتى مانند يردازش زئش

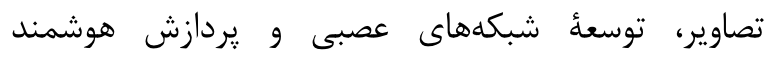

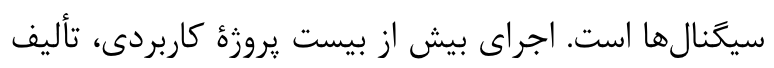

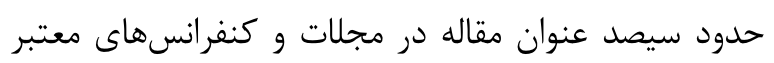

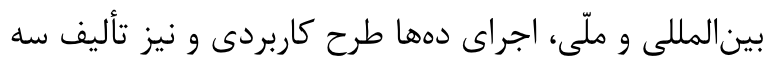

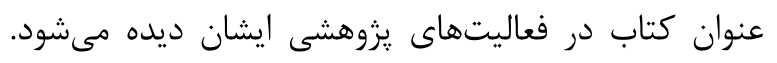

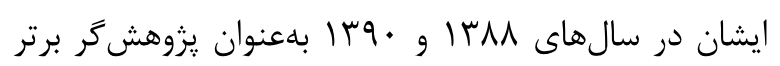

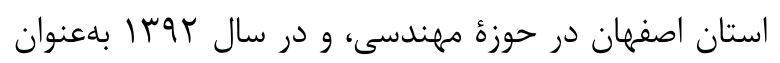

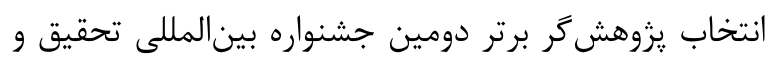
توسعه ايران، انتخاب شدهاند. p_moallem@eng.ui.ac.ir

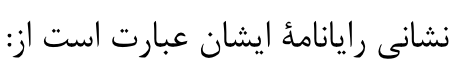

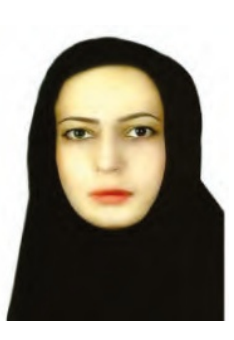

زهرا حنيفهلو، دانشجوى دكتراى

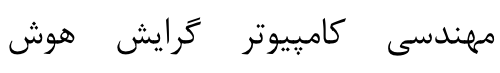
مصنوعى و رباتيك دانشخاه اصفهان

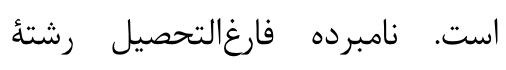
مهندسى كامييوتر در مقطع كارشناسى

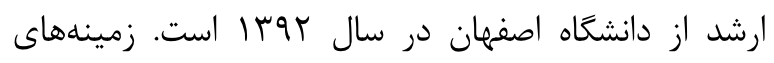
يزوهشى مورد علاقهُ وى شامل بينايى كامييوتر، بازشناسى الكَ و يردازش و تحليل سيخنال ها است. نشانى رايانامه ايشان عبارت است از: z.hanifelo@eng.ui.ac.ir

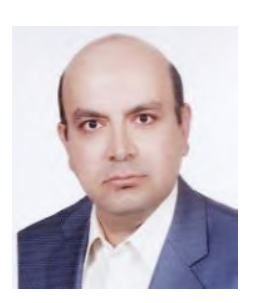

سيّداميرحسن منجمى، ليسانس مهندسى برق/كامييوتر خود را از دانشكاه صنعتى اصفهان در سال وعب ا اخذ كرد؛

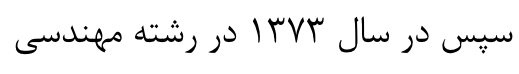
كامييوتر، هوش ماشين و رباتيك، موفق درس

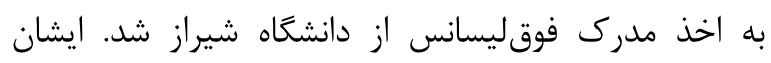

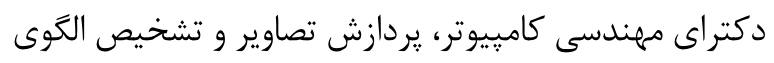

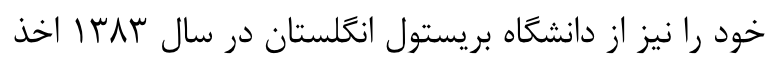

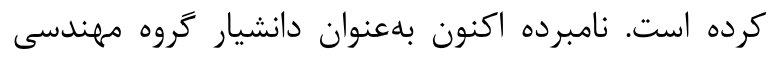

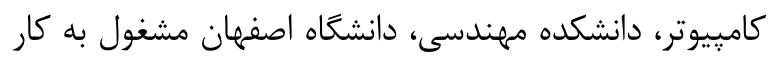
است. سرفصل هاى يزوهشى مورد علاقه وى، يردازش تصاوير و

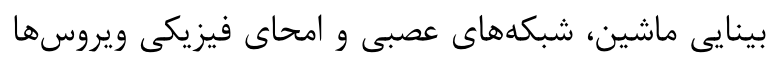

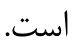
نشانى رايانامةٔ ايشان عبارت است از: monadjemi@eng.ui.ac.ir

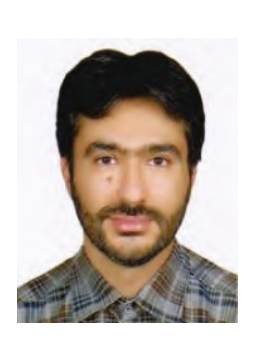
ييمان معلم متولد

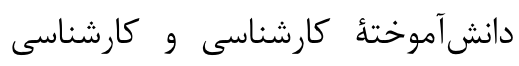

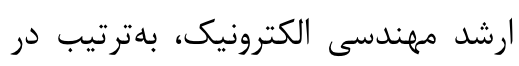

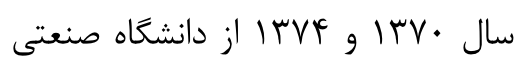
اصفهان و دانشعاه صنعتى اميركبير،

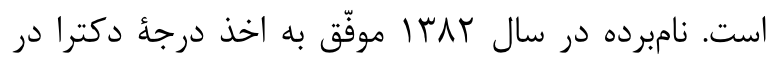

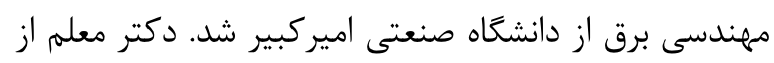

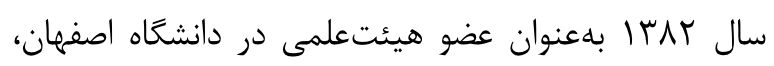

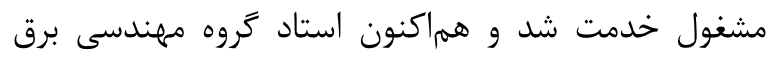


